Monatsschr Kinderheilkd 2009 • 157:493-514

DOI 10.1007/s00112-009-2007-9

(C) Springer Medizin Verlag 2009

\section{Abstracts und ausgewählte Vorträge der 17. Jahrestagung der Deutschen Gesellschaft für Pädiatrische Infektiologie (DGPI) zusammen mit der Gesellschaft für Kinder- und Jugendrheumatologie (GKJR)}

\author{
02. April bis 04. April 2009 in Bremen \\ Wissenschaftliche Leitung: \\ Prof. Dr. H.I. Huppertz und Prof. Dr. M. Borte
}

Tuberkulöse Meningitis

M. Knuf

Universitätskinderklinik Mainz

Die Tuberkulose ist in Deutschland mit 5.027 Fällen im Jahr 2007 (6.1/100.00o) eine präsente Erkrankung. Extrapulmonale Manifestationen machen etwa $20 \%$ der Tuberkulosefälle aus. Die tuberkulöse Meningitis (TM) ist sehr selten und betrifft vor allem Säuglinge und Kleinkinder, insbesondere dann, wenn ein Immundefekt vorliegt. Die Pathogenese der TM ist bislang nur unvollständig untersucht und verstanden. Die TM entsteht durch hämatogene oder lymphogene Aussaat von Mykobakterien mit Entstehung eines neuen „Primärkomplexes“(RICH-Komplex), der typischerweise subependymal, subpial oder in der Sylvisschen Fissur mit Kontakt zu den Meningen lokalisiert ist. Nach der Ruptur des „RICH-Komplexes“ entsteht die Meningitis. Die primäre Immunabwehr der Mykobakterien erfolgt vorrangig durch Mechanismen der zellulären Immunität, wenngleich durch neuere Untersuchungen Antikörper gegen $M$. tuberculosis (ESAT-6, 14kD, $19 \mathrm{kDa}, 38 \mathrm{kDa}$ ) im Liquor nachgewiesen werden konnten. Von großer Bedeutung sind dendritische Zellen in der Interaktion mit $\mathrm{CD}_{4+-}$ Zellen und Makrophagen. Hierbei werden pro-inflammatorische Zytokine ausgeschüttet (IL12, IL18, IL23, u.a.). Die bakterielle Replikation führt zu erhöhten Konzentrationen von IL8, TNFa und IFN $\gamma$ (nachweisbar im Liquor) und konsekutiver Vaskulitis, Meningitis und Enzephalitis. Begünstigt wird dieser Prozess durch das Einwandern von Neutrophilen und Lymphozyten bei gleichzeitiger Ausschüttung von IL1o in den Liquorraum. Die Zerstörung der Blut-HirnSchranke wird vermutlich und u. a. durch Matrix-Metallo-Proteinasen (MMP), welche von Monozyten und Makrophagen sezerniert werden, herbeigeführt. Die Bedeutung der MMP wird deutlich durch die gleichzeitige, antagonisierende Hochregulation von Gewebeinhibitoren der MMP. Es liegt eine Studie vor, die den quantitativen Zusammenhang von MMP-Konzentration und Therapieerfolg als Verlaufsparameter untersucht hat. Therapeutisch könnte IFN $\gamma$ als bedeutendes Effektorzytokin für die Kontrolle von Mykobakterien durch Makrophagen von Bedeutung sein. Wenngleich einzelne Aspekte der Pathogenese der TM untersucht sind, so bleiben doch viele Fragen noch offen.

\author{
Aktivierung der Immunantwort bei Pneumokokkenmeningitis \\ M. Klein \\ Neurologische Klinik, LMU München
}

Die Prognose der bakteriellen Meningitis bleibt trotz antibiotischer Therapie und intensivmedizinischer Versorgung schlecht. Insbesondere bei der Pneumokokkenmeningitis überleben ca. 15-25\% der Patienten nicht. Ein Grund für die hohe Letalität ist das häufige Auftreten von intrakraniellen Komplikationen wie Hydrozephalus, Hirnödem und arteriellen wie venösen Gefäßkomplikationen. Die körpereigene Immunantwort spielt für die Entstehung dieser Komplikationen eine entscheidende Rolle: Mäuse, die aufgrund eines genetischen Defekts keine oder nur eine eingeschränkte zerebrale Entzündungsreaktion ausbilden können, entwickelten in einem Modell der Pneumokokkenmeningitis weniger zerebrale Komplikationen. Vor allem die Produktion von reaktiven Stickstoff- und Sauerstoffradikalen durch in das Gehirn eingewanderte Entzündungszellen scheint für einen großen Teil der zerebralen Schädigung verantwortlich. Wie entsteht die Entzündungsreaktion? Bakterien können im Subarachnoidalraum zunächst weitgehend ungehindert proliferieren, da die Konzentration von opsonierenden Stoffen wie Komplementfaktoren und Antikörpern dort sehr gering ist. Schließlich kommt es zu bakterieller Autolyse und es werden multiple bakterielle Bestandteile wie Lipoteichonsäure, Peptidoglykan und Pneumolysin frei gesetzt, die von immunkompetenten Zellen durch Pathogenerkennungsrezeptoren (PRR) erkannt werden können. Im Mausmodell konnten durch den Einsatz von genetisch-defizienten Mäusen sogenannte Toll-like Rezeptoren (TLR) als zentrale immunaktivierende Rezeptoren bei Pneumokokkenmeningitis identifiziert werden. Insbesondere TLR2 (Rezeptor für Lipoteichonsäure) und TLR4 (Rezeptor für Peptidoglykan und Pneumoylsin) scheinen eine wichtige Rolle zu spielen, die die Entzündungsreaktion bei Pneumokokkenmeningitis voneinander unabhängig initiieren können. Während Pneumokokken in vitro auch über TLR9 (Rezeptor für bakterielle DNA) erkannt werden können, scheint TLR9 in vivo nur eine untergeordnete Rolle zu spielen. Durch den Einsatz von Knochenmarkschimären Mäusen konnte zudem gezeigt werden, dass vor allem perivaskuläre immunaktivierende Zellen entscheidend für die TLR2- und TLR4-abhängige Aktivierung der Entzündungsreaktion verantwortlich sind. Zusammengefasst scheinen TLR2 und TLR4 auf perivaskulären immunkompetenten Zellen eine wichtige Rolle für die Aktivierung des Immunsystems bei bakterieller Meningitis zu spielen. 
Nothing to cough at - detrimental effects of the NMDA receptor antagonist dextromethorphan in an experimental model of neonatal pneumococcal meningitis

J. Sellner ${ }^{(1,2)}$, R. Ringer ${ }^{(2)}$, P.Baumann ${ }^{(3)}$, M.Jonzier Perey ${ }^{(3)}$, B. Schmitt ${ }^{(4)}$, SL Leib ${ }^{(2)}$

${ }^{1}$ Department of Neurology, Klinikum rechts der Isar, Technische Universität

München, Germany

${ }^{2}$ Institute for Infectious Diseases, University of Bern, Switzerland

${ }^{3}$ Division of Clinical Neurophysiology, Children's University Hospital,

Zürich, Switzerland

${ }^{4}$ Departement de Psychiatrie, Site de Cery, University of Lausanne CHUV, Lausanne, Switzerland

Background and aims: A large proportion of neonates with bacterial meningitis will suffer from life-long neurological disability and academic limitations. The antitussive dextromethorphan (DM), an NMDA receptor antagonist capable of limiting excitotoxic damage, has shown clinical efficacy in a preliminary study of childhood bacterial meningitis. Hence, this study aimed at corroborating these observations together with an assessment of neuroprotective action of DM in an infant rat model of pneumococcal meningitis.

Methods: Neonatal rats were intracisternally infected with Streptococcus pneumoniae and antibiotic therapy with ceftriaxon $(100 \mathrm{mg} / \mathrm{kg})$ started at 18 hours after infection. Treatment with DM was started either at the time of infection $(4 \times 15 \mathrm{mg} / \mathrm{kg})$ or during acute meningitis $(2 \times 15 \mathrm{mg} / \mathrm{kg}$ and $2 \times 7.5 \mathrm{mg} / \mathrm{kg}$ ). The disease course was evaluated by a clinical composite score and presence of locomotor changes, epileptic seizures and ataxia. Neuronal damage was scored within the cortex (ischemic-necrotic damage) and the hippocampus (neuronal apoptosis within subgranular zone of the dentate gyrus).

Results: DM did not ameliorate the clinical course and did not protect from cortical and hippocampal neuronal injury. However, ataxia was induced when treatment was started during acute meningitis $(\mathrm{P}<0.03)$ and apoptotic neuronal injury within the hippocampal dentate gyrus increased when DM treatment started at the time of infection $(\mathrm{P}<0.05)$.

Conclusion: We conclude that adjuvant treatment with DM is not effective in attenuating pneumococcal meningitis and limiting neuronal injury in this animal model. Moreover, awareness for the use of DM is advised since this generally well-tolerated drug caused severe unwanted effects including increased hippocampal apoptosis and the induction of ataxia.

\section{Suilysin inhibiert die Invasion und Translokation von Streptococcus suis durch die Blut-Liquor-Schranke in vitro} T.Tenenbaum ${ }^{(1)}$, T.Papandreou ${ }^{(1)}$, D. Gellrich ${ }^{(2)}$, U.Friedrichs ${ }^{(2)}$, A. Seibt ${ }^{(2)}$, R. Adam ${ }^{(1)}$, C. Wewer ${ }^{(2)}$, HJ Galla ${ }^{(3)}$, C. Schwerk ${ }^{(1)}$ und H. Schroten ${ }^{(1)}$ 'Pädiatrische Infektiologie, Klinik für Kinder- und Jugendmedizin, Universitätsmedizin Mannheim

${ }^{2}$ Klinik für Allgemeine Pädiatrie, Heinrich-Heine Universität Düsseldorf ${ }^{3}$ Institut für Biochemie, Westfälische Wilhelms-Universität Münster

In vorangegangenen experimentellen Studien konnten wir in einem Standard Transwell-Filtersystem zeigen, dass der Meningitiserreger Streptococcus suis (S. suis) die Fähigkeit besitzt, die Barrierefunktion von porcinen choroidalen Plexusepithelzellen (PCPEC) zu beeinträchtigen. Die Etablierung eines, inversen 'Transwell-Filtersystems ermöglicht uns nun die bakterielle Invasion und Translokation von der physiologisch relevanten basolateralen (Blut-)Seite zur apikalen (Liquor-)Seite zu untersuchen. Kürzlich konnten wir eine spezifische Invasion und Translokation von S. suis über den PCPEC exklusiv von der basolateralen Seite aus demonstrieren. Während dieses Prozesses scheinen die Anwesenheit der Kapsel von S. suis, Zytoskelettregulierung der PCPEC sowie die Aufnahme in die bakteriellen Zellvakuolen eine Rolle zu spielen. In aktuellen Experimenten haben wir nun den Einfluss des thiol-aktivierten Hämolysins Suilysin auf Invasion und Translokation von S. suis durch PCPEC analysiert. Überraschenderweise konnte eine niedrigere Invasion und
Translokation bei drei unterschiedlichen Suilysin Mutanten im Vergleich zum S. suis Wild-Typ beobachtet werden. Dies steht im Gegensatz zu bereits publizierten Beobachtungen bei Endothelzellen, wo gezeigt werden konnte, dass Suilysin die Invasion in die Wirtszelle fördert. Suilysin vermag möglicherweise über die Induktion einer Signalkaskade den bakteriellen Internalisierungsprozess in PCPEC zu verhindern. Eine signifikant erhöhte Zytotoxizität durch die Suilysin Wild-Typen wurde nicht beobachtet. Unsere Daten unterstreichen die Relevanz der Blut-Liquor-Schranke als Eintrittspforte für Bakterien ins Zentralnervensystem. Weitere Experimente müssen jedoch die zellulären und molekularen Mechanismen für unsere Beobachtungen klären.

Parazelluläre und transzelluläre Transmigration von neutrophilen Granulozyten durch Epithelzellen des Plexus choroideus nach Infektion mit Streptococcus suis

C.Wewer ${ }^{(1)}$, A. Seibt ${ }^{(1)}$, HJ Galla ${ }^{(2)}$, MA Schmidt ${ }^{(3)}$, C. Schwerk ${ }^{(1,4)}$,

H. Schroten ${ }^{(1,4)}$, T. Tenenbaum $(1,4)$

'Pädiatrische Infektiologie, Klinik für Allgemeine Pädiatrie, Universitätskinderklinik Düsseldorf

${ }^{2}$ Institut für Biochemie, Westfälische Wilhelms-Universität Münster ${ }^{3}$ Institut für Infektiologie, Zentrum für Molekularbiologie der Entzündung (ZMBE), Westfälische Wilhelms-Universität/Universitätsklinikum Münster ${ }^{4}$ Pädiatrische Infektiologie, Kinderklinik, Universitätsklinikum Mannheim

Die strukturelle Basis der Blut-Liquor-Schranke wird durch die Epithelzellen des Plexus choroideus gebildet. Ein Bakterium, das den Plexus choroideus potentiell als Eintrittspforte in den Liquor nutzt, ist Streptococcus suis (S. suis). S. suis ist ein Schweinepathogen, welches eine Meningitis, Pneumonie oder Sepsis sowohl bei Schweinen als auch bei Menschen auslösen kann. Kürzlich konnten wir erstmalig in einem in vitro-System zeigen, dass S. suis Plexusepithelzellen spezifisch von der basolateralen Seite aus invadiert. Ein kritischer Punkt im Verlauf einer Meningitis ist der exzessive Einstrom von Leukozyten vom Blut in das Gehirn. Der Schaden, der durch eine Meningitis verursacht wird, wird z.T. durch die Inflammation und deren Folgen induziert. In unseren aktuellen Experimenten fokussierten wir daher auf Untersuchungen der Interaktion zwischen neutrophilen Granulozyten und dem Epithel des Plexus choroideus. Die Etablierung eines Umkehrkultursystems auf Transwell-Filtern ermöglichte uns, die Transmigration von neutrophilen Granulozyten von der physiologisch relevanten basolateralen (Blut) auf die apikale (CSF) Seite zu untersuchen. Wir konnten zeigen, dass die Migrationsrate der Neutrophilen durch PCPEC-Monolayer, die mit TNF $\alpha$ oder dem bekapselten S. suis WT Stamm 10 stimuliert wurden, signifikant höher lag, als durch nicht stimulierte Kontrollzellen. Die Transmigrationsrate von Neutrophilen durch S. suis WT Stamm 10 stimulierte PCPEC war außerdem signifikant höher als die durch mit kapseldefizientem S. suis stimulierten Zellen. Durch TNF $\alpha$ wurden der Transepitheliale elektrische Widerstand (TEER) und der parazelluläre Dextran-Fluss, durch S. suis nur der TEER signifikant beeinträchtigt. Inhibitionsexperimente mit Integrin-spezifischen Antikörpern zeigten, dass die Transmigration von neutrophilen Granulozyten vorwiegend CD11a, CD11R3 (entspricht dem humanen CD11b) und CD18 abhängig ist. Mit Hilfe von Apotome-Analysen in immunhistologischen Färbungen konnten wir demonstrieren, dass die neutrophilen Granulozyten die PCPEC-Monolayer sowohl parazellular als auch transzellulär überwinden. Diese Beobachtungen konnten durch elektronenmikroskopische Analysen bestätigt werden. In unseren Studien konnten wir erstmalig Mechanismen der Diapedese von neutrophilen Granulozyten durch die Blut-Liquor-Schranke am inversen in vitro-Zellkultursystem porciner Plexus choroideus Epithelzellen darstellen. Die Identifikation zahlreicher Integrine, die an der Transmigration durch PCPEC beteilig sind, liefert Ansätze für eine pharmakologische Intervention. 


\section{Phagocytic stress response in monocytes during Staphylococcus aureus infection \\ D. Holzinger ${ }^{(1)}$, J. Ehrchen ${ }^{(1)}$, D. Viemann ${ }^{(1)}$, G.Sander ${ }^{(2)}$, G.Peters ${ }^{(2)}$ and J. Roth ${ }^{(1)}$ \\ ${ }^{1}$ Institute of Immunology and ${ }^{2}$ Department of Medical Microbiology, University Hospital Münster, Germany}

Background: S. aureus is a common bacterial cause of severe skin and soft tissue infections, sepsis and systemic toxic reactions. The first line of defense after disruption of the epithelial barrier is the cellular innate immune system. Monocytes and macrophages are not only responsible for clearance of the pathogen but also induce and amplify the anti-bacterial inflammatory response. However, there are also reports indicating that $S$. aureus can survive within macrophages and thereby employ these cells as Trojan horses for systemic dissemination. Thus, we want to analyze the interaction between monocytes and different strains of $\mathrm{S}$. aureus, especially the slow-growing, small colony variant (SCV), which is known to cause recurrent and persisting infections.

Methods: Monocytes were cultivated in teflon bags and infected with different amounts of bacteria. The selected strains encompassed the clinical isolate 6850 , the laboratory strain Newman, the clinical isolate $3878 \mathrm{wt}$ and its SCV phenotype. After $2 \mathrm{~h}, 6 \mathrm{~h}, 24 \mathrm{~h}$ and $48 \mathrm{~h}$ the cells were harvested and cell death was checked. The intracellular persistence of bacteria was analyzed after lysis of monocytes. S. aureus induced gene expression of pro- and anti-inflammatory genes in monocytes was analyzed by RT-PCR. Results: RT-PCR performed $6 \mathrm{~h}$ after infection demonstrated induction of pro-inflammatory genes IL- 8 , TNF- $\alpha$, IL1- $\beta$, CCL-2o and CXCL-2. Thereby 6850 and 3878 showed the strongest induction in comparison to Newman and the $3878 \mathrm{SCV}$-variant. The same effect could be demonstrated for anti-inflammatory genes IL-10 and TNF-AIP-6. Furthermore, PI-staining demonstrated that increasing amounts of bacteria caused considerable death of monocytes ( $6850 \% 3 \mathrm{E} 3878 \mathrm{wt} \% 3 \mathrm{ENewman})$. However, the viability of monocytes were nearly unaffected by infection with the SCV phenotype. In parallel, the concentration of intracellular persisting bacteria was higher after infection with the SCV phenotype and Newman in contrast to 6850 and $3878 \mathrm{wt}$.

Conclusions: Our results demonstrate a clear inverse correlation between the capacity of different $S$. aureus strains to activate inflammatory gene expression in monocytes and their survival in these cells. These results encouraged us to initiate a genome wide analysis of the $\mathrm{S}$. aureus induced expression patterns in monocytes which should result in a better understanding of the molecular interaction between $\mathrm{S}$. aureus and the host innate immune system. This is a prerequisite for the development of novel therapeutic strategies aimed at the host immune system as an alternative to the development of new antibiotics against the increasing numbers of multidrug resistant $S$. aureus strains which comprise a severe health care problem worldwide.

\section{Erfolgreiches Management eines MRSA Ausbruchs auf einer neonato- logischen Intensivstation \\ Bartmann, A. Simon, G. Bierbaum, S. Engelhart}

Neonatologie, Pädiatrische Infektiologie, Mikrobiologie und Krankenhaushygiene, Universitätsklinikum Bonn

Einleitung: Infektionen und Kolonisation mit Methicillin- resistenten Staphylococcus aureus (MRSA) resultieren in signifikanter Morbidität und Mortalität und werden zunehmend auch aus neonatalen Intensivbereichen berichtet. Risiken für Kolonisation und Infektion sind die Unreife des Immunsystems und die Verwendung von Breitspektrum Antibiotika in dieser Patientengruppe. Wir berichten über das Managment eines MRSA Ausbruch in einer neonatologischen Intensiveinheit (NICU).

Patienten und Methoden: Alle Patienten, die während der endemischen (Feb.- Okt. 2005) und der epidemischen Phase (Nov.2005- Jan. 2006) des MRSA Ausbruchs auf der NICU aufgenommen wurden, wurden in die retrospektive Analyse eingeschlossen. Das MRSA Screening (Abstriche: nasal, pharyngeal, rectal) erfolgte erstmals 24 Stunden nach Aufnahme und dann wöchentlich. Während der epidemischen Phase des Ausbruchs wurden zusätzlich das gesamte Personal auf eine MRSA Kolonisation untersucht. Die mikrobiologischen Untersuchungen umfassten Kultur, PCR, und PFGE. Maßnahmen zur Eindämmung des Ausbruchs umfassten Isolierung, Kohortierung (epidemische Phase), Barrierepflege (Mundschutz, Kittel, Handschuhe), Schulungen der Mitarbeiter, und Etablierung eines Ausbruchsmangement Teams (epidemische Phase). Zur Dekolonisation der MRSA positiven Patienten und Personals wurden Polyhexanide- Waschlösungen und Mupirocin Nasensalbe verwendet. Bei Patienten mit gastrointestinaler Besiedlung wurde Vancomycin oder Linezolid oral appliziert.

Ergebnisse: Während der 11-monatigen Ausbruchsperiode hatten bei 358 Aufnahmen 27 Patienten mindestens einen positiven MRSA Befund. Der Indexpatient war ein Frühgeborenes der 34. SSW mit generalisierter Lymphangiektasie mit ersten positiven MRSA Nachweis im Aszites und Pleurasekret nach chirurgischer Pleurodese. Neben diesem Patienten hatte ein weiterer Patient eine milde Konjunktivitis mit MRSA Nachweis. Alle anderen Patienten waren kolonisiert, 15 (56\%) von 27 zeigten eine gastrointestinale Besiedlung mit erfolgreicher Eradikation in 3 von 10 Patienten. Insgesamt wurden von den 27 Patienten 8 als MRSA besiedelt entlassen oder in andere Kliniken verlegt. Von den verbleibenden 19 Patienten konnten 10 (53\%) eradiziert werden und 9 zeigten eine persistierende Kolonisation. Die Screening Untersuchungen von 142 Mitarbeitern ergaben 9 (6.3\%) besiedelte Personen, die alle mit Mupirocin MRSA dekolonisiert werden konnten. Alle MRSA Isolate der Patienten und 7 von 9 Isolate der Mitarbeiter zeigten in der Phagentypsierung und der PFGE die identische Charakteristika des epidemischen Rhein-Hessen MRSA Klon.

Schlussfolgerung: Ein konsequentes und aggressives Ausbruchsmanagement ist notwendig, um MRSA Ausbrüche frühzeitig zu beenden. Neben Screeninguntersuchungen mit Nasen- und Rachenabstrichen sollte bei Neugeborenen eine gastrointestinale Besiedlung ausgeschlossen werden. Die Dekolonisation von Patienten mit Besiedlung des Darmes scheint sehr schwierig zu sein.

Welche Folgen hat die Staphylococcus epidermidis-Sepsis für Frühgeborene?

C. Härtel, I. Osthues, C. Schultz, W. Göpel, E.Herting Klinik für Kinder- und Jugendmedizin Lübeck, UKSH Campus Lübeck

Einleitung: Staphylococcus epidermidis (S. epidermidis) ist der häufigste Erreger einer Late-Onset-Sepsis bei Frühgeborenen mit einem Geburtsgewicht < 1500 g (very-low-birth-weight, VLBW). Die langfristigen Auswirkungen einer S. epidermidis-Sepsis sind bislang nur unzureichend untersucht.

Methoden: 1) Unizentrische Studie zur In-vitro-Charakterisierung der S. epidermidis-induzierten Immunantwort in Nabelschnurblut von Frühund Neugeborenen 2) Multizentrische Evaluation der Auswirkungen einer S. epidermidis-Sepsis bei VLBW-Frühgeborenen im Rahmen des Netzwerks German Neonatal Network (GNN)

Ergebnisse: 1) Bei Frühgeborenen zeigte sich eine deutliche Abhängigkeit der intrazellulären Bildung der pro-inflammatorischen Zytokine IL-6 und TNF- $\triangle$ vom Gestationsalter $(\mathrm{R}=0.279, \mathrm{p}=0.002 ; \mathrm{R}=0.251$ bzw. $\mathrm{p}=0.005 ; \mathrm{n}=121$ ), während eine individuelle Regulation anti-inflammatorischer Zytokine nachweisbar war. In Überständen von Vollblutkulturen, die mit einem Biofilm-produzierenden, klinisch isolierten IcaABD positiven Stamm infiziert worden waren, zeigte sich im Vergleich zum IcaABD negative ATCC Stamm eine verringerte IL-6 Produktion $(\mathrm{p}=0.009)$. 2) VLBW-Frühgeborene, die eine S. epidermidis-Sepsis erleiden ( $n=172 / 2042 ; 8.4 \%)$, haben ein erhöhtes Risiko weiterer Komplikationen, u.a. bronchopulmonale Dysplasie (BPD), intraventrikuläre Hämorrhagie (IVH), Operation (OP) wegen nekrotisierender Enterokolitis (NEC) oder behandlungsbedürftige Retinopathie.

Schlussfolgerungen: Die S. epidermidis-Sepsis ist ein wichtiger Einflussfaktor der Langzeitmorbidität von Frühgeborenen. Kenntnisse zum 
individuellen Risikoprofil, incl. Immunantwort, sind bedeutsam, um langfristig Präventionsmaßnahmen zu optimieren.

\section{IRAK4 und MyD88-Defekt prädisponieren zu bakteriellen Infektionen H.v.Bernuth \\ Klinik für Kinderheilkunde der Charité mit Schwerpunkt Pneumologie und Immunologie,Berlin}

IRAK4 und MyD88-Defekt sind verwandte, kürzlich beschriebene, Immundefekte. Beide sind durch die fast vollständige Beeinträchtigung Toll-like Rezeptor und IL-1 Rezeptor vermittelter Immunität gekennzeichnet. Inzwischen ist der Verlauf von 32 Patienten mit IRAK4-Defekt und 1o Patienten mit MyD88-Defekt bekannt. Die größte Gefahr stellen Pneumokokkenerkrankungen dar, die bei 28 Patienten auftraten (bei 15 Patienten als tödliche Meningitis). Infektionen durch andere Bakterien wie Staphylococcus aureus $(n=20)$, Pseudomonas aeruginosa $(n=6)$, Shigella sonnei $(n=2)$ und Salmonella enteritidis $(n=2)$ wie Arthritis, Osteomyelitis, Sepsis, eitrige Lymphadenitis, Abszesse innerer Organe und der Speicheldrüsen, Sinusitis, abszedierende Tonsillitis und Orbitalphlegmone sind ebenfalls dokumentiert. 11 Patienten litten unter wiederkehrenden Hautinfektionen durch S. aureus. Alle Patienten erlitten die erste lebensgefährliche Infektion vor dem Ende des dritten Lebensjahres, 25 Patienten vor der Vollendung des ersten Lebensjahres und sechs innerhalb der Neonatalperiode. Verschiedene Infektionen wurden bei fast allen Patienten beobachtet, ebenso rezidivierende Infektionen durch denselben Erreger, insbesondere durch S. pneumoniae. Die einzige Ausnahme stellen drei Patienten dar, die seit unmittelbarer postpartaler Diagnose prophylaktisch antibiotisch behandelt werden. Ein verzögerter Nabelschnurabfall wurde bei vier Patienten beobachtet. Typisch waren unverhältnismäßig niedrige Entzündungszeichen (Temperatur, $\mathrm{CrP}$ ) trotz schwerer Infektion. Die Patienten zeigten bei normaler Eiterbildung häufig Neutropenien. Unbehandelt ist der klinische Verlauf mit 15 verstorbenen Patienten innerhalb der ersten Lebensjahre ungünstig. Jenseits des 8. Lebensjahres sind keine Todesfälle und jenseits des 14 . Lebensjahrs sind keine invasiven Infektionen mehr berichtet worden. Zusammenfassend sind Patienten mit IRAK4 und MyD88-Defekt durch lebensbedrohliche bakterielle Erkrankungen im Säuglings- und Kleinkindalter gefährdet. Ab der Adoleszenz scheint die Prognose deutlich verbessert.

\section{Immunologisches Monitoring von Fieber-in-Neutropenie-Episoden PT Oommen, C. Härtel}

Klinik für Kinder-und Jugendmedizin Lübeck, UK-SH Campus Lübeck

Einleitung: Fieber ist zumeist das einzige Symptom einer infektiösen Komplikation bei onkologisch erkrankten Kindern mit therapiebedingter Neutropenie. Spezifische Marker, die frühzeitig die Diagnose einer Infektion sichern, stehen gegenwärtig nicht zur Verfügung. Diese Untersuchung hatte zum Ziel, die angeborene Immunantwort von onkologisch erkrankten Kindern vor Beginn der Therapie und im Verlauf von Fieber-in-Neutropenie-Episoden zu charakterisieren.

Methode: Quantitative Bestimmung von Zytokinen der angeborenen Immunantwort (basale Expression; Stimulation mit Lipopolysaccharid -LPS- als Wandbestandteil gramnegativer Erreger; Stimulation mit Staphylococcus epidermidis in Vollblutkulturüberständen mittels enzymgebundenem Immun-Assay (ELISA).

Ergebnisse: 1) Es zeigte sich bei Kindern vor Chemotherapie $(n=20)$ im Vergleich zu gesunden Kontrollkindern keine signifikant unterschiedliche Zytokinantwort nach In-vitro-Zusatz von LPS oder S. epidermidis. 2) Die basale Expression von Interleukin (IL)-8 im Verlauf von Fieberin-Neutropenie-Episoden $(\mathrm{n}=30)$ ist individuell sehr unterschiedlich. 3) Während zum Zeitpunkt der Diagnose „Fieber-in-Neutropenie“ kaum eine signifikante Stimulationsantwort auf LPS oder S. epidermidis in den Immunzellen der Patienten nachweisbar war, zeigte sich bis zum Tag 7 der Antibiotikatherapie eine nahezu vollständige Erholung der angeborenen Immunantwort auf Ausgangswerte vor der Chemotherapie. Schlussfolgerungen: Immunologisches Monitoring von Fieber-in-Neutropenie-Episoden kann wichtige Erkenntnisse zur „Erholung der angeborenen Immunantwort“ der Patienten erbringen und eine frühzeitige Beendigung der zumeist empirischen antibiotischen Therapie im Individualfall unterstützen.

Deutschlandweite Impfstudie- Länderbezogene Ergebnisse zur Impfeinstellung, zum Impfverhalten und zum Erleben von Impfkomplikationen von niedergelassenen Kinderärzten, Praktikern und Allgemeinmedizinern

R. Bruns ${ }^{(2)}$, W. Hoffmann ${ }^{(1)}$

${ }^{1}$ Institut für Community Medicine, Abt. Versorgungsepidemiologie und Community Health ${ }^{2}$ Zentrum für Kinder- und Jugendmedizin, Ernst-Moritz-Arndt-Universität Greifswald

Problem: In Deutschland ist Impfrecht Länderrecht. Dabei richten sich seit einigen Jahren alle Bundesländer nach den Empfehlungen der STIKO. Die Durchimpfungsraten impfpräventabler Erkrankungen in Deutschland sind insgesamt unbefriedigend, unterliegen aber deutlichen regionalen Unterschieden.

Methoden: Im Rahmen einer repräsentativen Querschnittserhebung wurden 3020 Kinderärzte (50\% Zufallsstichprobe aller Kinderärzte) sowie 4282 Praktiker und Allgemeinmediziner (10\% Zufallsstichprobe aller Allgemeinmediziner) aus allen Bundesländern angeschrieben und ihnen ein standardisierter Fragebogen zur Beantwortung zugesandt. Adressquellen waren je nach Bundesland die Verzeichnisse der Ärztekammern, Kassenärztlichen Vereinigungen oder das Internet.

Ergebnis: Von den angeschriebenen Kinderärzten kam bei 2023 (67\%) und von den Allgemeinmedizinern bei 1736 (41\%) eine Rückmeldung. Die Rekrutiereffizienz (REP = Anteil zurückgesandter ausgefüllter Fragebögen bezogen auf alle erreichten Ärzte) lag bei 62\% für die Kinderärzte und 39\% für die Allgemeinmediziner. In der gesamten BRD gaben $61 \%$ der befragten Kinderärzte an, sowohl vom Umfang als auch im Zeitablauf gemäß den STIKO-Empfehlungen zu impfen. Dabei liegen die Werte für die einzelnen Bundesländer zwischen $83 \%$ in Sachsen-Anhalt und $49 \%$ in Bayern ( $\mathrm{p}<\mathrm{0}, 0001)$. Betrachtet man die Studienorte dieser Pädiater, so lässt sich hier feststellen, dass Kinderärzte mit Medizinstudium im Ausland sich ähnlich fest nach den STIKO-Vorgaben richten $(57 \%$, $\mathrm{n}=74)$ wie Solche, die in Deutschland studiert haben $(61 \%, \mathrm{p}=0,46)$. Des Weiteren ist festzustellen, dass, egal wo praktizierend, bei einem Studium in Sachsen-Anhalt $80 \%$ und in Bayern $48 \%$ der späteren Kinderärzte angeben, gemäß STIKO-Vorgaben zu Impfen $(\mathrm{p}<0,0001)$. Bei den Allgemeinmedizinern ergibt sich ein ähnliches Bild: $63 \%$ der Befragten geben an, gemäß STIKO-Vorgaben zu impfen. Dabei liegen die Angaben für die einzelnen Bundesländer zwischen $82 \%$ für Thüringen und $52 \%$ für Bayern $(\mathrm{p}<0,0001)$. Auch hier sind, je nach Studienort, Unterschiede vorhanden: $55 \%$ der Allgemeinmediziner mit Auslandsstudium halten sich an die STIKO-Vorgaben $(n=42)$ gegenüber $63 \%$ bei denen mit Studium in Deutschland $(\mathrm{p}=0,25)$. Die Unterschiede innerhalb der BRD (Schleswig-Holstein: 52\%, Mecklenburg Vorpommern: 83\%, $\mathrm{p}=0,0003$ ) sind hier analog zu beobachten wie innerhalb Berlins (Berlin Ost: $71 \%$, Berlin West: 49\%, p=o,0122). Was das Erleben von Impfreaktionen/komplikationen/-schäden betrifft, so gaben ca. 31\% der Kinderärzte und $30 \%$ der Allgemeinmediziner an, schon einmal eine Impfnebenwirkung gesehen zu haben, wobei nur $1 \%$ der Kinderärzte und $2 \%$ der Allgemeinmediziner schrieben, schon einmal wegen eines Impfschadens belangt worden zu sein.

Schlussfolgerung: Die Studie erbrachte für alle Bundesländer repräsentative Informationen zu wichtigen Determinanten der Impfpraxis niedergelassener Haus- und Kinderärzte, wie z.B. die Akzeptanz der STIKO-Empfehlungen. 


\section{Poncet Rheumatismus bei aktiver mediastinaler Tuberkulose}

N. Neudecker' ${ }^{1}$, T. Hospach' ${ }^{1}$ K. Magdorf ${ }^{2}$, G. Dannecker ${ }^{1}$

'Klinikum Stuttgart, Olgahospital, Pädiatrie 1

${ }^{2}$ HELIOS Klinikum Emil v. Behring, Lungenklinik Heckeshorn, Berlin

Ein16-jähriges, aus Sri Lanka stammendes Mädchen stellt sich mit Fieber vor. Bei mediastinaler Raumforderung mit Epitheloidzellinfiltrate und zentralen Nekrosen sowie positivem Hauttest und Elispot stellten wir die Diagnose einer Tuberkulose. Zusätzlich entwickelte die Patientin im Verlauf eine Polyarthritis mit papulo-nodulärem Exanthem. Dieses Krankheitsbild nennt sich Poncet-Rheumatismus und ist eine seltene, aseptische Form einer reaktiven Polyarthritis bei aktiver Tuberkulose. Die adäquate Therapie besteht in einer antituberkulotischen Medikation sowie, in seltenen Fällen, dem Einsatz von Steroiden.

\section{Efficacy of MMR revaccination in children with juvenile idiopathic arthritis treated with Methotrexate and Etanercept \\ S.Borte $\left({ }^{1}, 2\right)$, UG Liebert ${ }^{(3)}$, U. Sack ${ }^{(1)}$, M. Borte ${ }^{(2)}$ \\ ${ }^{1}$ Department of Clinical Immunology and Transfusion Medicine, ${ }^{2}$ Depart- ment of Pediatrics, Municipal Hospital „St Georg“ Leipzig, and ${ }^{3}$ Department of Virology, University of Leipzig, Germany}

Objectives: To evaluate the influence of low-dose Methotrexate and Etanercept treatment on efficacy of measles, mumps and rubella revaccination (MMR) in children with juvenile idiopathic arthritis. Vaccinations in JIA represent a debatable problem because of the very limited data on safety, efficacy and immunogenicity in particular.

Methods: A prospective nested case-control study was performed to investigate markers of MMR revaccination induced humoral and cellmediated immunity in 15 patients with juvenile idiopathic arthritis (ages 6-17 years), treated with either low-dose Methotrexate (MTX) therapy alone or in combination with Etanercept. The control group consisted of 22 healthy children. Production of Interferon- $\gamma$ (IFN $\gamma$ ) by T memory cells upon in vitro stimulation with measles, mumps and rubella antigens and seroprevalence of virus-specific IgG antibodies were assessed. Medication use, disease activity and patients comments on side-effects were observed during the period of 6 months before and after revaccination. Results: Low-dose MTX therapy following MMR vaccination proved not to hamper $\mathrm{T}$ cell mediated immunity in vitro. Neither low-dose MTX nor Etanercept treatment, given simultaneous to revaccination, markedly interfered with generation of long-lived virus-restricted $\mathrm{T}$ cells and protective levels of virus-specific IgG antibodies. No increase in disease activity or medication use was seen within 6 months after MMR revaccination, including JIA-patients using Etanercept. No overt measles, mumps, rubella or secondary severe infections were noted.

Conclusions: Low-dose MTX and Etanercept treatment do not seem to interfere with intended outcome of MMR revaccination in children with JIA.

\section{2-jährige Patientin mit Oligoarthritis nach Infektion mit Influenza B-Virus \\ N. Bruck \\ Klinik und Poliklinik für Kinder- und Jugendmedizin, Universitätsklinikum Carl Gustav Carus, TU Dresden}

Einleitung: Eine Arthritis kann sich nach verschiedenen Virusinfektionen oder Influenza-Immunisierung entwickeln, ist jedoch unseres Wissens noch nicht nach Influenza- Infektion beschrieben worden.

Fallbericht: Ein 12-jähriges Mädchen entwickelte im Februar 2008 eine typische Grippesymptomatik mit hochfieberhaften Temperaturen, Lichtempfindlichkeit sowie Glieder- und Kopfschmerzen. Aus dem Nasenrachenabstrich wurde mittels PCR und Viruskultur eine Influenza B Infektion gesichert. Unter konservativer Therapie war die Symptomatik über fünf Tage rückläufig. Ca. drei Wochen später kam es zu einer schmerzhaften Schwellung mit Rötung und Überwärmung im Bereich des proximalen Interphalangealgelenkes (PIP) der linken Mittelzehe und, eine Woche später, des Metatarsophalangealgelenkes (MTP) der linken Großzehe. Zudem bestand eine allgemeine Abgeschlagenheit und Krankheitsgefühl, jedoch kein Fieber. Unter Therapie mit Ibuprofen besserten sich die Beschwerden über vier Wochen. Bei der darauffolgenden rheumatologischen Vorstellung fiel eine deutliche Versteifung der PIPGelenke der ersten bis dritten Zehe links sowie Druckschmerz des MTP-Gelenkes der Großzehe sowie des PIP-Gelenkes der dritten Zehe auf. Laborchemisch war auffällig: Eosinophilie von $9 \%$. Normwerte bestanden für CrP, BSG, restliches Blutbild, Ferritin, Antistreptolysintiter, Rheumafaktor und antinukleäre Antikörperl; ausgedehnte Virus- und Borrelien-Serologien waren negativ. Unter der Annahme einer durch Influenza B-Virus bedingten postviralen Synovialitis behandelten wir symptomatisch mit NSAR und Physiotherapie. Ca. sechs Wochen später kam es erneut zu einer akuten schmerzhaften Rötung und Schwellung des MTP-Gelenkes der Großzehe links. Die Therapie erfolgte mit intraartikulärer Injektion von $6 \mathrm{mg}$ Triamcinolon-Hexacetonid. Bei Wiedervorstellung nach drei Monaten war die Patientin beschwerdefrei und hatte die volle Funktion der betroffenen Gelenke wiedererlangt.

Schlussfolgerung: Obwohl eine Kausalität hier nicht zu beweisen ist, deutet dieser Fall daraufhin, dass eine Infektion mit Influenza B-Viren zu einer postviralen Arthritis führen kann.

\section{Das Transkriptionsinferno der Uratkristall-Inflammation \\ F. Pessler}

Klinik und Poliklinik für Kinder- und Jugendmedizin, TU Dresden

Urat (Harnsäure)-Kristalle verursachen eine akute Entzündungsreaktion, die kritisch von der Aktivität von Toll-like Rezeptoren (TLR) 2 und 4 sowie dem Nalp3-Inflammasom Multiproteinkomplex abhängt. Diese Faktoren spielen fundamentale Rollen in der Pathogenese infektiöser als auch akut und chronisch entzündlicher Prozesse. Injektion von Uratkristallen in die murine „air pouch“ verursacht eine Entzündungsreaktion, die stark einer akuten Synovialitis bei Menschen ähnelt. Mit Hilfe von isolierten „air pouch“ Membranen und custom low density PCR Arrays für 96 Zielgene haben wir die hauptsächlichen Transkriptionsveränderungen während eines kompletten, 50-stündigen Zeitkurses der Uratkristall-Inflammation in einem einfachen, der Synovialmembran ähnlichen Gewebe charakterisiert. Im Durchschnitt bestand eine maximale 100-fache Induktion aller signifikant regulierter mRNAs. Diese Induktion gipfelte 4 Stunden nach Injektion der Kristalle auf und fiel während der folgenden 46 Stunden allmählich ab. Euklidische Distanzähnlichkeits-Analyse identifizierte eine dramatische transkriptionelle Umprogrammierung zu dem $4 \mathrm{~h}$ Zeitpunkt. Die Ansammlung von Leukozyten im Inneren der „pouch“ folgte einer eigenen, langsameren Kinetik und erreichte ihr Maximum erst 9 h nach Injektion der Kristalle. Hierarchische Clustering-Analyse identifizierte 3 Wellen von zeitlich co-regulierten mRNAs: eine frühe, steil ansteigende Welle, welche die großen pro-inflammatorischen Zytokine IL-1beta, IL-6 und TNF-alpha beinhaltetel; sodann eine anhaltendere Welle, die Matrix Metalloproteinasen und Faktoren des Prostaglandingstoffwechsels und der TLR Signaltransduktion einschloss $\mid$; und schließlich eine ausgedehnte Resolutionsphase, charakterisiert durch erhöhte Expression entzündungshemmender Faktoren wie Prostaglandin D Synthase, TGF-beta und der Transkriptionsfaktor PPAR-gamma. 
Die extraintestinale Yersiniose: eine seltene (?) schwer abzugrenzende Differentialdiagnose

K. Linnemann ${ }^{(1)}$, R. Bruns ${ }^{(1)}$, J.-P. Haas $\left({ }^{1},{ }^{2}\right)$

${ }^{1}$ Allgemeine Pädiatrie, E.-M.-Arndt-Universität, Zentrum für Kinder- und Jugendmedizin, Greifswald

${ }^{2}$ Deutsches Zentrum für Kinder- und Jugendrheumatologie, GarmischPartenkirchen

Problem: Infektionen mit Yersinia enterocolitica gelten als möglicher Trigger reaktiver Arthritiden im Kindes- und Jugendalter. Pathogenetische Erklärungsmodelle reichen von molekularer Mimikry über Erregerpersistenz bis zu autoimmunologischen Mechanismen sind aber im Wesentlichen noch unklar. Im Kindes- und Jugendalter existieren nur Einzelfallberichte zu Therapie und Verlauf bei extraintestinaler Yersiniose mit assoziierter reaktiver Arthritis. Ziel dieser Fallzusammenstellung ist eine Darstellung des Spektrums juveniler Yersinieninfektionen mit assoziierter reaktiver Arthritis.

Methoden: Verglichen wurden die klinischen und paraklinischen Befunde von 5 Kindern im Alter von 11 - 18 Jahren mit einer extraintestinalen Yersiniose, die aufgrund einer Arthritis in unserem Zentrum vorgestellt wurden. Fall 1: Mädchen, 18 J, Coxitis bds. seit 4,5 Jahren, Yersinia enterocolitica IgG 930U/ml (\%3 $\left.{ }_{2} 20\right)$, IgA 26,1 (\%3 C10), Western-Blot (IgA positiv), Therapie: Ibuprofen intermittierend und Meloxicam für 8 Wochen|; Verlauf: Keine Vollremission, anhaltende Schmerzenl; jetzt Betreuung durch Allgemeinmediziner bei Volljährigkeit Fall 2: Mädchen 13J, Coxitis rechts vor 18 Monaten, Yersinia enterocolitica IgG 973 U/mll; IgA 19,6 U/ml, Western-Blot (IgA negativ), Therapie: Ibuprofen für 8 Wochenl; Verlauf: anhaltende Vollremission Fall 3: Knabe 17J, Polyarthritis seit 5,5 Jahren, Yersinia enterocolitica IgG 635 U/ml, IgA 17, Western-Blot (IgA positiv), Therapie: Ibuprofen intermittierend।; Verlauf: Keine Remission, Schmerzverstärkungssyndrom, z.Z. ohne Therapie Fall 4: Mädchen 16,5J, Coxitis rechts vor 3,5 Jahren, Yersinia enterocolitica IgG $27,3 \mathrm{U} / \mathrm{ml}$, IgA 17,8 , Western-Blot (IgA positiv), Therapie: keinel; Verlauf: Spontanremission Fall 5: Mädchen 16,5J, Gonarthritis vor 5 Jahren, Yersinia enterocolitica IgG $140 \mathrm{U} / \mathrm{ml}$, IgA 11,1, Western-Blot (IgA positiv), Therapie: anfänglich Ibuprofen, Cefotaxim für 10 Tage und Doxycyclin für 8 Wochen, Sulfasalazin für 13 Monate, zuletzt MTX für 3o Monate, Verlauf: Übergang in eine Enthesitis-assoziierte JIA (juvenile idiopathische Arthritis), seit 2 Jahren Vollremission

Ergebnis: Unsere Patienten zeigten ein typisches Gelenksverteilungsmuster mit vorwiegendem Befall der unteren Extremität. Persistierende IgAAntikörper werden als pathognomisch für eine Yersiniose angenommen. Es erhebt sich die grundlegende Frage, ob es sich um eine koinzidente oder eine kausale Beziehung handelt.

Zusammenfassung: Ein Therapieversuch mit NSAID erscheint sinnvoll. Eine antibiotische Therapie ist von fragwürdigem Wert. Die insgesamt schlechte Datenlage lässt ein Überdenken der gängigen Therapieempfehlungen sinnvoll erscheinen.

\section{Makrophagenaktivierungssyndrom als Erstmanifestation einer SJIA M. Scheler. A. Sauerbrey HELIOS Klinikum Erfurt, Klinik für Kinder- und Jugendmedizin}

Hintergrund: Das Makrophagenaktivierungssyndrom (MAS), auch bezeichnet als sekundäre hämophagozytische Lymphohistiozytose (HLH), ist charakterisiert durch hohes Fieber und Hepatosplenomegalie bzw. eine Dysfunktion der Leber, seltener Lymphknotenvergrößerung, Exantheme und Pleuraerguss oder Aszites. Die typischen laborchemischen Veränderungen beinhalten eine Zytopenie, eine Hyperferritinämie, eine Erhöhung der LDH, eine Hypofibrinogenämie und eine Hypalbuminämie. Im Knochenmark können aktivierte Makrophagen und eine Hämophagozytose gesehen werden. Das Krankheitsbild wird meist durch sekundäre Infektionen, v.a. mit Viren oder Medikamente bei vorbestehenden autoimmunen oder malignen Grunderkrankungen (insbesondere Leukämien und Lymphome) ausgelöst. Es kommt zu einer Aktivierung von Lymphozyten und Makrophagen und zu einer konsekutiven massiven Ausschüttung proiflammatorischer Zytokine, was insgesamt ein infektiös-septisches Krankheitsbild mit Hypovolämie, respiratorischer Insuffizienz, disseminierter intravasaler Gerinnung und neurologischen Ausfallserscheinungen imitieren kann. Trotz intensiver Therapie ist das MAS mit einer Letalität zwischen 30 und 50 \% verbunden.

Fallbericht: Unsere Patientin litt an einem kleinfleckig-konfluierenden Exanthem, sowie im Verlauf zusätzlich an Arthralgien und rezidivierendem Fieber. Aufgrund der Persistenz der Symptomatik und einer deutlichen Verschlechterung des Allgemeinzustandes kam es zur Hospitalisation. Im Verlauf verschlechterte sich die Patientin, trotz Antibiotikatherapie und wiederholten Prednison-Gaben zunehmend, so dass unter der Arbeitsdiagnose einer Sepsis eine intensivmedizinische Überwachung und Therapie erfolgte. Sie entwickelte ausgeprägte Pleuraergüsse und musste nicht-invasiv beatmet werden. Unter der Verdachtsdiagnose eines akuten Abdomens wurde eine diagnostische Laparoskopie durchgeführt. Insgesamt konnte trotz intensiver Suche kein infektiöser Fokus gefunden werden. Nach Konsultation unserer Klinik erfolgte eine Knochenmarkpunktion, die Hinweise auf eine HLH ergab, was uns in Verbindung mit der Anamnese sowie der typischen Klinik und Paraklinik zur Diagnose eines MAS bei einer systemisch beginnenden juvenilen idiopathischen Arthritis führte. Wir entschlossen uns zur sofortigen Therapie mit VP-16 und Ciclosporin A sowie mehreren Hochdosis-Methylprednisolon-Pulsen. Die Therapie sprach rasch an und die Patientin konnte auf Normalstation verlegt werden. Im Verlauf entwickelte sie eine polyartikuäre Arthritis und erneute Fieberschübe, weshalb die Therapie um MTX und Anakinra erweitert wurde. Aktuell ist die Patientin unter alleiniger Therapie mit oralem Methotrexat komplett beschwerdefrei und erfreut sich bester Gesundheit.

Schlussfolgerungen: Das Makrophagenaktivierungssyndrom ist eine seltene komplizierende Erkrankung bei rheumatischen Erkrankungen, insbesondere bei der systemische verlaufenden Form der juvenilen idiopathischen Arthritis. Insgesamt muss man davon ausgehen, dass es sich um ein stark unterdiagnostiziertes Krankheitsbild handelt, welches aber aufgrund seiner potentiellen Lebensbedrohlichkeit eine rasche Diagnose und Therapie erfordert. Daher ist es für nahezu alle klinisch tätigen Ärzte, insbesondere in der Pädiatrie, wichtig die klinischen und laborchemischen Merkmale zu kennen und die Diagnose bei unklaren, septisch imponierenden Krankheitsbildern in die eigenen differentialdiagnostischen Überlegungen einzuschließen, sowie im Falle einer klaren Diagnose unverzüglich eine wirksame Therapie einzuleiten.

\section{Hypophosphatasia - recent advances in pathogenesis, diagnosis and treatment \\ C. Beck ${ }^{(1)}$, M. Stenzel(2), HJ Girschick ${ }^{(1)}$ \\ 1) Children's hospital and ${ }^{2}$ ) Department of Radiology, University of Würz- burg, Germany}

Hypophosphatasia (HP) is a rare inborn error of bone and mineral metabolism characterized by a genetic defect in the gene of the tissue non-specific alkaline phosphatase (TNSAP) Clinical symptoms include defective bone mineralisation with bone deformities, fractures and recently defined chronic non-bacterial osteomyelitis. Renal damage due to calcification, dental abnormalities with premature loss of dentition and craniosynostosis are further symptoms. Laboratory assays, genetic counselling and testing, and radiologic imaging can confirm the diagnosis. Calcium pyrophosphate dihydrate (CPPD) crystals are known to accumulate as substrates of TNSAP in tissues and joints of patients with HP. Knowledge on the mechanisms underlying crystal-induced cell activation, however, is limited. Here we describe recent advances in elucidating the signal transduction pathways activated by CPPD crystals as endogenous "danger signals". Recent investigations provided evidence that Toll/interleukin-1 receptor (TIR) domain containing receptors including toll-like receptors (TLRs) and interleukin-1 receptor (IL-1R), as well as the triggering receptor expressed on myeloid cells 1 (TREM-1) and the NALP 3 (NACHT-leucin rich repeat and pyrin-domain-containing protein) containing inflammasome are essentially involved in acute CPPD crystal-induced inflammation. These receptors are considered in 
part as components of the innate immune system. Further studies are needed to improve our understanding of the pathophysiological mechanisms leading to inflammation and tissue destruction associated with deposition of microcrystals. They might support the development of new therapeutic strategies for crystal-induced inflammation. Eventually, also patients with HP might profit from such strategies addressing these metabolic disorders secondary to the gene defect. As long as there is no curative treatment of hypophosphatasia, symptomatic treatment in order to improve clinical features, especially with regard to pain and physical activity, is of major interest to the patients. Because symptoms are highly variable in their clinical expression, patients should be followed by a HPexperienced multidisciplinary team.

\section{Foudroyanter Verlauf der Erstmanifestation eines systemischen Lupus erythematodes (SLE) bei invasiver Pneumokokkeninfektion A. Bigl, M.Schulz, W.Siekmeyer, B. Hügle, C. Gebauer, A. Rodloff, V. Schuster Universitätsklinik und Poliklinik für Kinder und Jugendliche Leipzig}

Patienten mit SLE haben ein deutlich erhöhtes Risiko an einer bakteriellen Infektion zu erkranken. Genetische Disposition und andere Faktoren (aktuelle Krankheitsaktivität, immunsuppressive Therapie, Defekte in der Immunfunktion) wirken hier als Risikofaktoren zusammen und beeinflussen signifikant die Schwere und den Verlauf der Infektion.

Wir stellen eine 13jährige Patientin vor, die mit Polyarthritis und intermittierendem Fieber bis $39^{\circ} \mathrm{C}$ seit ca. 3 Wochen in unserer Klinik vorgestellt wurde. Nach 6 Tagen kam es zu einer rapiden klinischen Verschlechterung mit Pneumonie, erstmaligem Auftreten eines schmetterlingsförmigen Erythems im Gesicht sowie einer Vigilanzverschlechterung. Paraklinisch fand sich eine rapid zunehmende Erhöhung des Ferritins (von initial 226,8 $\mu \mathrm{g} / \mathrm{l}$ bis auf $>10000 \mu \mathrm{g} / \mathrm{l}$ ) sowie eine ausgeprägte Hypergammaglobulinämie (IgG 26,4 IU/ml). Autoantikörper (u.a. ANA $>$ 1:5120, anti-dsDNA-AK >200) waren hochtitrig positiv. Aufgrund einer zunehmenden respiratorischen Insuffizienz musste das Kind maschinell beatmet werden. Im weiteren Verlauf entwickelte sich ein ARDS. In der Blutkultur konnten Pneumokokken vom Serotyp ${ }_{19}$ F nachgewiesen werden, die vermutlich die schlechte pulmonale Situation begünstigten. Bei akuter neurologischer Verschlechterung mit lichtstarren Pupillen wurde ein CT durchgeführt. Hier zeigte sich ein generalisiertes Hirnödem. Trotz Osmotherapie mit Mannitol, antiinfektiver Therapie mit Meronem und Caspofungin und immunsupressiver Therapie mit Methyprednisolon und Cyclophosphamid, verstarb die Patientin nach 4 Tagen im Multiorganversagen. Bei 6 von 11 erfüllten ACR Kriterien konnte die Diagnose SLE gestellt werden. Postmortem wurden eine eitrige Pachymeningitis, sowie mehrere septikopyämische Herde in Herz, Lunge und Gehirn festgestellt. Möglicherweise hat die schwere S.pneumoniae-Sepsis und Meningitis zu dem foudroyanten und letztlich fatalen Verlauf eines SLE geführt. Es stellt sich die Frage, inwieweit die Immunisierung mit einem Pneumokokkenimpfstoff solche schweren Komplikationen auch bei Patienten mit SLE verhindern kann.

\section{MRSA - Infektion und Kolonisation - eine neue Herausforderung in der Pädiatrie \\ A. Beyersdorff. ${ }^{(1)}$, R. Bruns ${ }^{(1)}$, H. Bahlmann'), G. Schröder ${ }^{(2)}$, RD Stenger ${ }^{(1)}$ Ernst-Moritz-Arndt-Universität Greifswald, ${ }^{(1)}$ Klinik und Poliklinik für Kin- der- und Jugendmedizin, ${ }^{(2)}$ Institut für Medizinische Mikrobiologie}

Einführung: Staphylokokken sind bekannte nosokomiale Erreger. Die Kolonisation und Infektion mit MRSA haben bei erwachsenen Risikopatienten in Deutschland dramatisch zugenommen. Auch in Geburtseinrichtungen, Kinderkliniken und Kinderpflegeheimen werden zunehmend Einzelfälle beobachtet. Anhand eigener Erfahrungen wird über diese Problematik berichtet. Patienten und

Methode: In einem Zeitraum von 1 1/2 Jahren beobachteten wir bei 8 Patienten (2 weibl., 8-15 J., 6 männl., Geburt-10 J.) Kolonisationen und Infektionen durch MRSA. Alle Patienten wurden bei positiven MRSA-
Befunden (positive PCR und positive Kultur) sofort isoliert, nach einem einheitlichen Hygieneregime saniert, der Klinikumshygienearzt und ggf. weitere Einrichtungen (vorbehandelnde Kliniken, Pflegeeinrichtungen, Krankentransport) zeitnah informiert. Bei allen Patienten wurde ein Sanierungsversuch durchgeführt.

Resultate: Kolonisationsorte mit MRSA waren häufig mehrfach (Nasenvorhöfe, Perineum, Gastrostoma). In 3 Fällen erfolgte der MRSA-Nachweis im Rahmen einer Infektionsdiagnostik (Paronychie, purulente Konjunktivitis, tracheobronchiales Aspirat). 5 Patienten (Risikopatienten) waren chronisch krank (1 Patient, 7 J., mit Trisomie 21 mit MDS, VSD, portaler Hypertension und mehrfachen operativen Eingriffen, 4 Patienten, 7-15 J., mit schwerer Hirnschädigung und Begleitsymptomatik). Bei einem Frühgeborenen (28. SSW), einem reifen Neugeborenen und einem Trimenonsäugling konnte im Rahmen der stationären Behandlung (ANS, Aufzucht; Epilepsie-Diagnostik; Bronchopneumonie und purulente Konjunktivitis) MRSA nachgewiesen werden. Die simultane MRSA-Diagnostik der Eltern war in 4 Fällen, bei den jüngsten Patienten generell, positiv ( 3 x Mütter, 1 x Vater). Bis auf das Frühgeborene konnten alle Patienten saniert werden. 3 Risikopatienten hatten bei weiteren stationären Aufenthalten erneut positive MRSA-Befunde. Die häusliche Sanierung von kolonisierten Patienteneltern war nur teilweise erfolgreich. Diskussion: Alle chronisch Pflegebedürftigen (in Pflegeeinrichtungen, häufige Klinikaufenthalte) müssen schon im Kindesalter als Risikopatienten für MRSA-Besiedlung angesehen werden. Bei jeder stationären Wiederaufnahme oder bekannter MRSA - Anamnese müssen sie bis zum diagnostischen Ausschluss nach einem strengen Hygieneregime isoliert werden. Die Sanierung zur Keimeradikation ist dringend indiziert. Für Angehörige mit direktem Kontakt gibt es derzeitig leider keine gesetzliche Sanierungspflicht. Schlussfolgerungen: In den kommenden Jahren ist auch in der Pädiatrie mit einer zunehmenden MRSA-Besiedlung zu rechnen. Aus diesem Grunde muss das ärztliche und pflegerische Personal mit dieser Problematik vertraut gemacht und frühzeitig mit einer protektiven Barrierepflege und Sanierung begonnen werden. Das schließt auch die Geburtshilfe ein.

\section{Mehrere Fälle von caMRSA in der Pädiatrie: Know-how tut not} T. Schwanz, S. Scheithauer, H. Häfner, S. Lemmen

Zentralbereich für Krankenhaushygiene und Infektiologie, Universitätsklinikum Aachen

Einleitung: Community acquired Methicillin-resistente Staphylococcus aureus (caMRSA) sind nach Berichten tödlich verlaufender Infektionen durch diese Erreger bei zuvor gesunden Kindern in den Blickpunkt des Interesses gerückt. Auch wenn sich die epidemiologische Situation in Deutschland noch erheblich von der US-amerikanischen unterscheidet, sollten rezidivierende und/oder schwer verlaufende Hautinfektionen an diese Erreger denken lassen.

Fallbericht: Aufnahme eines 4-jährigen Mädchens mit ausgeprägter Paronychie, die eine operative Sanierung indizierte: im Abstrich fand sich MRSA. In der weiteren Untersuchung der Familie erwiesen sich Eltern und Großeltern sowie die 6-jährige Schwester als MRSA negativ; der 2jährige Bruder war im Nasen-Rachen mit MRSA besiedelt, eine klinische Symptomatik lag nicht vor. In der Familie eines Spielgefährten der Indexpatientin wurde bei einem weiteren Geschwisterkind und dem Vater in den vorangegangenen Monaten über behandlungsbedürftige Abszesse berichtet; beide erwiesen sich im Nasen-Rachen-Abstrich als MRSA Träger. Die Mutter der Familie war nicht besiedelt; beide Elternteile arbeiten als Kliniksärzte. Alle nachgewiesenen MRSA Stämme konnten dem spa (Staphylococcus aureus Protein A-Gen)-Typen oo8 zugeordnet werden und waren Panton-Valentin-Leucocidin (PVL)-Toxin positiv; dieser Typ entspricht dem caMRSA-Klon USA30o, der als besonders virulent gilt. Im weiteren Verlauf entwickelte der 2- jährige Bruder der Indexpatientin, der bereits als MRSA Träger identifiziert werden konnte, einen operationsbedürftigen Glutealabszess. Trotz der bekannten Kolonisation erfolgte die ambulante Therapie mit Ampicillin/Sulbactam, das nicht caMRSA wirksam ist. Trotz wiederholter und gründlicher Sanierungsmaßnahmen 
persistierte die MRSA Kolonisation im Windelbereich des Zweijährigen. Alle übrigen Personen konnten erfolgreich saniert werden.

Schlußfolgerung: Wissen um adäquate Diagnostik und effektive Therapie ist vor dem Hintergrund der zunehmenden Verbreitung von CAMRSA mit erhöhter Virulenz PVL positiver Stämme auch in der Pädiatrie unabdingbar. Epidemiologische Kenntnisse sind als Grundlage für etwaige Sanierungsmaßnahmen sinnvoll.

\section{Salvage Treatment with Posaconazole in Pediatric Patients A Multi- center Survey \\ AH. Groll, A. Attarbaschi, S.Luer, R. Phillips, T.Wiesel, HJ Wagner, B.Gruhn and T.Lehrnbecher \\ Children's Hospitals of Muenster, Vienna, Berne, Leeds, Datteln, Giessen, Jena and Frankfurt}

Background: Posaconazole is a new antifungal triazole with potent and broad spectrum antifungal activity and approved prophylactic and therapeutic indications. While a pediatric dosage has not been defined, posaconazole is occasionally used in pediatric patients. We conducted a multicenter retrospective survey in order to obtain data on pediatric patients considered to require posaconazole salvage therapy.

Methods: The survey identified 10 patients $\% 3 \mathrm{C}_{1} 8$ years of age (median age: 10.4 years; range, $3.6-15.5 ; 5 \mathrm{f}, 5 \mathrm{~m}$ ) with hematologic malignancies (7), bone marrow failure (1), solid tumor (1), and soft tissue trauma (1) who received posaconazole for proven ( 7 ) or probable (3) invasive fungal infections (zygomycosis (5), mold infection (3), aspergillosis (1), chronic disseminated candidiasis (1)). Posaconazole was administered until intolerance or until maximum efficacy at dosages individually determined by the responsible physician on the basis of refractory infection (6), intolerance of other agents (1) or as best therapeutic option (3) following pretreatment with other systemic antifungal agents for a median of 19 days ( $r$, 4-112).

Results: The 10 patients received posaconazole for a median of 31 days ( $\mathrm{r}$, 4 to 163 ) as single agent (4) or in combination (6). The median daily dosage was $20.5 \mathrm{mg} / \mathrm{kg}$ (95\% CI, 14.6-25.8।; r, 4.8-32). In none of patients was therapy discontinued due to adverse events. Irrespective of their causal relationship, clinical adverse events were mild to moderate and observed in 8 patients $(80 \%)$. Mean GOT, GPT, bilirubin, alkaline phosphatase and creatinine values in serum at end of treatment were not different from those at baseline. Complete or partial responses were observed 3/5 patients with zygomycosis, 2/3 patients with invasive mold infections, o/1 patient with invasive aspergillosis and $1 / 1$ patient with chronic disseminated candidiasis. Altogether, 5 patients had a complete, and 1 patient a partial response, accounting for an overall response rate of $60 \%$. Overall survival at three months post end of treatment was $70 \%$ ( $7 / 10)$.

Conclusion: Although this assessment is limited by its retrospective nature, variability in dosage and combination therapy in most patients, posaconazole displayed favorable safety and tolerance and was useful in managing individual pediatric patients with invasive fungal infections. A dose-finding clinical trial is currently under way to initiate the pediatric development of the compound.

\section{Zygomycoses in Pediatric Patients: A report from the ECMM Survey} AH. Groll, K.Tintelnot, U.Wintergerst, N.Jendreyko, F. Schuster, B. Kremens, A.Attarbashi, L.Schrod and T.Lehrnbecher Children's Hospitals of Muenster, Munich, Goettingen, Essen, Vienna, Frankfurt-Hoechst, Frankfurt am Main and Robert Koch Institut, Berlin

Background: Zygomycosis is associated with high morbidity and mortality and is perceived as emerging fungal infection. However, contemporary epidemiological data are limited. In 2004, the European Confederation for Medical Mycology (ECMM) has initiated a prospective survey to collect data on the occurrence of zygomycosis in Europe. Here, we present an interim analysis of pediatric cases reported to the registry from Germany and Austria until December 2008.
Methods: The survey is based on the voluntary reporting of cases by clinicians and laboratories via national coordinators to the study center using a standardized, anonymized case report form. Submission of isolates or paraffinized tissue specimen for further laboratory investigations is encouraged. Proven zygomycosis is defined by compatible clinical and/or radiographic findings and microbiological identification of the organism, and probable zygomycosis by compatible clinical and/or radiographic findings plus microscopic detection in diagnostic specimens. All cases are reviewed and adjudicated as necessary by the national coordinator (AHG).Prior to its start, the survey was approved by the Ethics Committee of the University Hospital Muenster.

Results: 12 cases from 9 centers were reported between January 2004 and December 2008 (2004: 3; 2005: 4; 2006: 1; 2007: 3: 2008: 1). Six patients were male, and six were femalel; the mean age was 12.6 (r, o.1 to 17) years. The majority of patients $(67 \%)$ was either treated for acute myeloid leukemia (3), acute lymphatic leukemia (2), lymphoma (1) and severe aplastic anemia (1), or had received an allogeneic hematopoietic stem cell transplant (1); during the aplastic phase). Other conditions included insulin-dependent diabetes mellitus (2), soft tissue trauma, and lung hypoplasia with extracorporal membrane oxygenation (1 patient each). Zygomycosis was proven in 9, and probable in 3 cases. Isolates included Absidia (5), Rhizopus (3), and Mucor (1) species. Infection was limited to soft tissue in 3 cases, the lung in 2 cases, and an infected central thrombus in 1 casel; sinoorbital-cerebral disease was found in 3 cases, and pulmonary-mediastinal, pulmonary-cerebral and soft tissuecerebral involvement in 1 case each. All 3 patients with isolated soft tissue infection were cured, whereas 7 of the remaining patients died ( 2 pts without follow-up).

Conclusion: While these data are far from providing the full extent of disease burden of zygomycoses in pediatric patients in Germany, they reflect the continuing threat of these infections to immunocompromised patients and the need for improved diagnosis and management.

\section{Behandlung einer Aspergillus flavus Infektion bei einem Frühgebore- nen durch eine Therapie mit Amphotericin und Caspofungin}

\section{S. Bagci, A. Simon, P. Bartmann, A. Müller}

Neonatologie und Pädiatrische Infektiologie, Zentrum für Kinderheilkunde, Universitätsklinikum Bonn

Einleitung: Die Therapie einer invasiven Pilzinfektion bei Früh- und Neugeborenen sind oft schwierig. Wir stellen ein extrem unreifes Frühgeborenes mit einer disseminierten Aspergillus flavus und Candidainfektion vor, die durch eine Kombinationstherapie mit Amphotericin B und Caspofungin erfolgreich behandelt wurde.

Fallbeschreibung: Ein männliches Frühgeborenes, $24+1$ SSW, Geburt per Sectio bei Amnioninfektionssydrom, Geburtsgewicht 77og. Bei auffälligen Abdomen und V.a. einen Mekoniumileus wurde am 7. LT ein Kolon-Kontrasteinlauf durchgeführt, der eine Perforation im Bereich des Ileums zeigte. Eine sofort durchgeführte Laparotomie zeigte ein Mikrokolon, mehrere Ileumnekrosen mit Perforation sowie eine Colonperforation. Am 12. LT trat eine vom Nabel ausgehender Hautmykose durch Aspergillus flavus auf, die systemisch mit liposomalen Amphotericin B und Caspofungin sowie Amphotericin B lokal und oral behandelt wurde. Die wegen der weiterhin bestehenden abdominellen Symptomatik durchgeführte Relaparotomie am 24. LT ergab multiple intraabdominelle Pilzabszesse sowie eine Leberteilnekrose mit Nachweis von Candida parapsilosis. Die histologische Untersuchung ergab eine abszedierende Entzündung im Lebergewebe sowie floride und granulierende Entzündung im Dünndarm mit Nachweis Aspergillus. Die anschließende Wundheilung verlief unproblematisch. Die Caspofungin-Behandlung wurde ohne erkennbare Nebenwirkungen am 45. LT und die systemische Amphotericin-Behandlung am 55. LT beendet.

Schlussfolgerung: Lebensbedrohliche Pilzinfektionen bei neonatologischen Patienten haben eine hohe Mortalität. Die Kombinationstherapie mit Caspofungin könnte eine mögliche Alternative in der Behandlung sein. 
Retrospektive Analyse der Prophylaxe und Therapie invasiver Pilzinfektionen in einem kinderonkologischen Zentrum - das Überleben hat seinen Preis

PD Hasan, T.Dresbach, J. Gillen, G. Fleischhack, U. Bode, A. Simon

Zentrum für Kinderheilkunde, Universitätsklinikum Bonn

Hintergrund: Zur Indikationen und Auswahl antimykotischer Medikamente für die Prophylaxe und Therapie invasiver Pilzinfektionen (IFI) bei immunsupprimierten Kindern und Jugendlichen liegen keine Evidenz-basierten Konsensuskriterien vor. Ein erheblicher Teil der Arzneimittelkosten pädiatrisch onkologischer Zentren wird durch einige wenige Antimykotika verursacht.

Methoden: Retrospektive Analyse des Einsatzes von Fluconazol, Itraconazol, Voriconazol, Posaconazol, Caspofungin und liposomalem Anphotericin B (AmBisome ${ }^{\oplus}$, L-AMB) von Februar 2007 bis Februar 2008. Ergebnisse: Während des Beobachtungszeitraumes wurden 113 Patienten (medianes Alter 8.9 Jahre) stationär behandelt, von denen $n=43$ (38\%) insgesamt 52 Zyklen einer antimykotischen Prophylaxe und $n=20$ (18\%) insgesamt 42 Zyklen einer antimykotischen Therapie erhielten. Die Indikationen für die Prophylaxe waren: solider Tumor und autologe SCT (19\%), Sekundärprophylaxe nach IFI (17\%). ALL und Dexamethason (17\%), Intensive Therapie mit oder ohne Steroide (15\%), Hochrisiko NHL (10\%), Hochrisiko ALL vor KMT 8\%, ALL Rezidiv (8\%), AML 4\%) und hochgradige Immunsuppression bei SAA, MDS oder HLH 2\%). $63 \%$ aller Prophylaxezyklen wurden ohne Modifikation beendet, $17 \%$ erforderten wegen FUO, $13 \%$ Zyklen wegen einer IFI und $2 \%$ wegen $\mathrm{Ne}$ benwirkungen eine Modifikation. Die Indikation für die Therapie waren FUO > 96 h 36\%, Candida-Infektionen der Haut und Schleimhaut $19 \%$, mögliche IFI $14 \%$, wahrscheinliche IFI $10 \%$ und gesicherte IFI $21 \%$. Modifikationen der Therapie wurden erforderlich bei $40 \%$ aller FUO, $13 \%$ aller superfizialen Candida-Infektionen, 33\% aller möglichen IFI, $50 \%$ aller wahrscheinlichen IFI und 89\% aller gesicherten IFI. In 12 von 42 Behandlungszyklen (29\%) wurde eine Kombinationstherapie verabreicht. Die Gesamtkosten der antimykotischen Prophylaxe und Therapie beliefen sich in 12 Monaten auf ca. 180.00o Euro. Kein Patient starb an den Folgen einer IFI, obgleich schwerste disseminierte IFI beobachtet wurden. Bei keinem Patienten wurde die Chemotherapie wegen einer IFI beendet.

Zusammenfassung: Diese Studie liefert erstmals detaillierte Daten zur Prophylaxe und Therapie von IFI in einem deutschen kinderonkologischen Behandlungszentrum. Die in den letzten Jahren erreichte Reduktion der Letalität von IFI bei kinderonkologischen Patienten erfordert erhebliche Investitionen in Diagnostik, Prophylaxe und Therapie, die in den jetzigen Sachmittelbudgets nicht ausreichend abgebildet sind.

\section{Analyse und Unterbindung möglicher Übertragungswege nach gehäuftem Auftreten von Infektionen mit oxacillinresistenten koagu- lasenegativen Staphylokokken (CoNS) auf einer neonatologischen Intensivstation \\ U. Schulze-Sturm ${ }^{(1)}$, L. Dreiser ${ }^{(1)}$, A. Kappler (2) J. Runde ${ }^{(1)}$, JH Schwalm ${ }^{(1)}$ G. Selzer ${ }^{(1)}$, HI Huppertz ${ }^{(1)}$ \\ ${ }^{1}$ Prof. Hess-Kinderklinik und Klinik für pädiatrische Intensivmedizin und Neonatologie, Klinikum Bremen Mitte \\ ${ }^{2}$ Institut für allgemeine Hygiene, Krankenhaushygiene und Umwelthygiene}

Hintergrund: CoNS gehören zu den häufigsten Erregern nosokomialer Sepsis auf neonatologischen Intensivstationen. Hauptrisikofaktoren einer Sepsis mit CoNS sind geringes Geburtsgewicht und Gestationsalter sowie Fremdkörper wie zentrale Venenkatheter. Wir beobachteten eine Häufung von Sepsisfällen bei Frühgeborenen mit einem Geburtsgewicht unter 1500 g mit Nachweis oxacillinresistenter CoNS auf unserer neonatologischen Intensivstation innerhalb der ersten Jahreshälfte 2008. Um mögliche Übertragungswege zu verfolgen und zu unterbrechen, wurden eine Keimtypisierung sowie eine Umgebungsuntersuchung durchgeführt.
Methode: Die Genotypisierung der Erreger der zwei zum Zeitpunkt der Untersuchung noch erkrankten bzw. besiedelten Patienten wurde mittels Pulsfeldgelelektrophorese durchgeführt. Gleichzeitig erfolgte eine systematische mikrobiologische Umgebungsuntersuchung der neonatologischen Intensivstation sowie der Reanimationseinheit des Kreißsaals mit Erreger- und Keimzahlbestimmung sowie Genotypisierung bei Nachweis von S.haemolyticus.

Ergebnisse: Im ersten Halbjahr 2008 traten bei bis dahin 45 aufgenommenen Patienten mit Geburtsgewicht $<1500$ g 13 Fälle von Sepsis durch CoNS auf; davon 8 Fälle mit S.haemolyticus. Dies war eine deutliche Häufung gegenüber 2007; hier traten bei einer Patientenzahl von 76 (im gesamten Jahr) 5 Fälle auf, darunter kein S.haemolyticus). Durch die Genotypisierung konnte eine Infektion mit dem gleichen Genotyp von S.haemolyticus bei den beiden untersuchten Patienten nachgewiesen werden. In der Umgebungsuntersuchung wurden insgesamt 5 verschiedene Genotypen isoliert. Dabei zeigte sich eine Kontamination mit dem Genotyp der erkrankten Patienten an unterschiedlichen Stellen, insbesondere an Windelwaagen sowie Dichtungsringen von Inkubatoren. Nach gezielter Modifikation der hygienischen Maßnahmen (z.B. noch häufigeres Auswechseln der Inkubatordichtungen, Desinfektion der Windelwaage auch durch die Eltern) zeigten erneute Umgebungsuntersuchungen eine deutlich reduzierte Keimzahl an den Geräten im Vergleich zur Voruntersuchung. Im zweiten Halbjahr 2008 traten nur noch zwei Fälle von CoNS-assoziierter Sepsis auf; S.haemolyticus wurde dabei nicht mehr nachgewiesen.

Diskussion: Ein epidemiologischer Zusammenhang mit den vorausgegangenen, nicht genotypisierten Erregern der S.haemolyticus-assoziierten Sepsisfälle ist nicht zu beweisen, aber naheliegend. Durch die kontinuierliche interne Surveillance, die Evaluation möglicher Übertragungswege und die konsequente Umsetzung hygienischer Maßnahmen können Fälle nosokomialer Infektionen, in unserem Beispiel die Sepsis durch oxacillinresistente CoNS, wirksam in ihrer Häufigkeit verringert werden.

\section{Disseminated Bartonella henselae Infection Mimicking Langerhans ${ }^{`}$ Cell Histiocytosis}

I.Janz, A. Brentrup, K. Keyvani, K.Becker, T.Linden and AH. Groll

Departments of Pediatric Hematology and Oncology, Neurosurgery, Neuropathology and Clinical Microbiology, University Hospital Münster, Münster, Germany

Background: Bartonella henselae, the causative agent of cat scratch disease, has been recognized to be responsible for a broad range of clinical syndromes. Here we report the case of disseminated B. henselae infection mimicking Langerhans' cell histiocytosis at presentation and its successful management with neurosurgery, prolonged antibacterial therapy and observation.

Case report: The patient was a previously healthy, 11-year-old girl who was admitted at an outside hospital with recurrent fever ${ }_{3} \mathrm{E}_{3} 9^{*} \mathrm{C}$, malaise and laboratory signs of systemic inflammation. While the initial work-up was negative for a defined infectious or autoimmune disorder, the pt subsequently developed a moderately painful soft tissue mass on the left temporal bone. Imaging studies revealed a circumscript lytic skull lesion as well as focal lesions within the liver. A tentative diagnosis of Langerhans cell histiocytosis (LCH) was made, and the pt referred to our institution. On admission, the pt. was afebrile and in stable general condition. Except for the $8 \mathrm{~cm} \varnothing$ large soft tissue mass, physical examination was unremarkable. Laboratory studies confirmed mild anemia, a C-reactive protein of $6.8 \mathrm{mg} / \mathrm{dL}$ (nl: \%3Co.5), an erythrocyte sedimentation rate of $95 \mathrm{~mm} / \mathrm{h}$, and a total IgG of $2420 \mathrm{mg} / \mathrm{dL}$ (nl: \%3C1500). Ferritin, triglycerides, tumor markers and bone marrow studies were within normal limits।; blood cultures and routine serologies remained non-contributory. Further imaging confirmed an isolated $1 \mathrm{~cm} \varnothing$ lytic skull lesion, several hypodense lesions in liver and spleen, and additional focal lesions in the lung. Following an interdisciplinary case conference, a resection biopsy of the skull lesion was performed. Histopathology revealed necro- 
tizing inflammation without evidence for $\mathrm{LCH} \backslash$; cultures, special stains, immunohistochemical and extended molecular studies were negative for a specific etiology. Further work-up revealed close contact to cats and highly elevated anti- B.henselae IgG and IgM titers (1:6400 and 1:200, respectively). In the absence of another etiology, a diagnosis of disseminated B.henselae infection was made based on the criteria set forth by Margileth (2000). The pt was started on a prolonged course of oral azithromycin (200 mg BID for 12 weeks) followed by observation. Fever episodes, malaise, and headaches completely resolved within 3 months along with declining inflammatory parameters; first signs of regression of hepatic lesions occurred after 6 months. Fifteen month following diagnosis, the $\mathrm{pt}$ is in complete clinical remission with residual calcified liver lesions of $\% 3 \mathrm{C} 0.6 \mathrm{~cm}$. The B.henselae IgG titer has decreased to $1: 1600$ while the IgM is negative.

Conclusions: This case report illustrates the expanding spectrum of B.henselae infection and the need to include this organism in the differential of prolonged fever syndromes. The therapeutic approach to these infections must be individualized on the basis of the patient's clinical presentation and immune status.

\section{Diagnostische Evaluation der Tuberkulose im Kindesalter in Malawi, Afrika: erste Ergebnisse einer aktuellen Studie N.Heinrich ${ }^{(1)}$; J.Chimphamba ${ }^{(2)}$; K.Reither ${ }^{(1)}$; J.Jung ${ }^{(1)}$; F.Salaniponi ${ }^{(3)}$; M. Born ${ }^{(5)}$; A. Simon ${ }^{(4)}$; A.Müller ${ }^{(4)}$; M.Hoelscher ${ }^{(1)}$ ${ }^{1}$ Abteilung für Infektions- und Tropenmedizin, Klinikum der LMU Mün- chen; ${ }^{2}$ Our Lady of Mount Carmel Hospital, Kapiri, Malawi, ${ }^{3}$ National TB Control Programme, Lilongwe, Malawi; ${ }^{4}$ Pädiatrische Infektiologie, Zentrum für Kinderheilkunde, Universitätsklinikum Bonn ${ }^{5}$ Abteilung für Diagnostische Radiologie, Universitätsklinikum Bonn}

Ziel der Studie: Die vorgestellte Untersuchung evaluiert neue Diagnostika bei Tuberkulose im Kindesalter in einem Krankenhaus in Malawi/ Afrika.

Methode: Untersuchung von Sputum, induziertem Sputum oder Magensaft von Kindern mit Tuberkulose (TB) - Verdacht im Kapiri Community Hospital, Malawi. Gleichzeitige Anwendung von zwei neuen Diagnostika (Urin LAM-ELISA; Quantiferon ${ }^{\circledR} \mathrm{TB}$ Gold) zur Kalkulation der Sensitivität dieser Tests anhand von Kultur-positiven Fällen. Kalkulation der Sensitivität nach Identifikation von 25 Kultur-positiven Fällen. Bestimmung der Spezifität durch Untersuchung von 1oo Patienten ohne respiratorische Infektion.

Ergebnisse: Seit September 2007 wurden 70 Kinder mit TB-Verdacht mittels Sputumbakteriologie untersucht. Nur bei zwei Kindern konnte eine Tuberkulose diagnostiziert werden. Überraschenderweise fanden sich bei 16 Kindern (23\%) Mykobakterien bisher unbekannter Spezies im Sputum. Nachdem zwei dieser Kinder unerwartet verstarben, führten wir ein Follow-up dieser Gruppe durch. Dieses ergab unter den 13 evaluierbaren Patienten: 19\% verstorben, $38 \%$ Symptombesserung, $25 \%$ fortbestehende respiratorische Symptome. Von 11 Kindern liegen Röntgenuntersuchungen zum Zeitpunkt des Follow-ups vor, davon sind $63 \%$ mit aktiver oder abgelaufener TB vereinbar, $36 \%$ unauffällig. Aus der Gruppe der kultur-negativen Patienten wurden keine Todesfälle berichtet.

Schlussfolgerungen: Die Diagnostik der Tuberkulose mittels Kultur von induziertem Sputum ist in diesem Setting weniger erfolgreich, als anhand von einschlägigen Publikationen erwartet. Die Kultur von Magensaft wird nunmehr zusätzlich durchgeführt. Die noch nicht ausreichend charakterisierten atypischen Mykobakterien, die bei 16 von 70 Kindern mit TB-Verdacht gefunden wurden, repräsentieren möglichweise bisher unbekannte pathogene Spezies.
Brucellose unter dem Bild einer fieberhaften thrombozytopenischen Purpura

N. Salimi, A. Kupczyk, J. Matten, M. Weiß, R. Cremer

Kliniken der Stadt Köln GmbH Kinderkrankenhaus Riehl Amsterdamer Str., Köln

Die Brucellose gilt als schwierig zu diagnostizierende Infektionskrankheit, da die auftretenden Symptome sehr vielfältig sein können. Wegweisend sind undulierendes Fieber, Hepatosplenomegalie und Lymphadenitis. Wir behandelten einen Patienten, bei dem diese typische Befundkonstellation nicht vorlag, sondern das klinische Bild einer thrombozytopenischen Purpura dominierte.

Fallbericht: Ein 7-jähriger, türkischer Junge mit Fieber unklarer Ursache, generalisierten Gelenkschmerzen sowie petechialen Hautblutungen zeigte Phasen von Abgeschlagenheit, Krankheitsgefühl und Erbrechen. Bei der Diagnostik fanden wir eine Thrombozytopenie (41/nl), eine leichte Anämie ( $\mathrm{Hb} 10,4 \mathrm{~g} / \mathrm{dl})$ sowie eine diskrete LDH- Erhöhung (350 $\mathrm{U} / \mathrm{l})$. Das CrP war mit 6,9 mg/l fast normwertig, die BSG mit 30mm/h leicht erhöht bei weiter rezidivierenden Fieberschüben. In der bei klinischer Aufnahme entnommenen Blutkultur wurde nach 6 Tagen Brucella melitensis nachgewiesen. Bei wiederholter Anamnese wurde ein 3 Monate zurückliegender Aufenthalt in der Türkei, bei dem der Patient der Schlachtung einer Ziege beigewohnt hatte, berichtet. Unter der antibiotischen Kombinationstherapie aus Cotrimoxazol und Rifampicin über 6 Wochen kam es rasch zur Entfieberung und Besserung der klinischen Symptomatik. Nach 2 Wochen musste jedoch aufgrund eines durch Cotrimoxazol ausgelösten Arzneimittelexanthems das Sulfonamid durch Gentamicin ersetzt werden. Nach weiteren 1o Tagen folgte wegen der kumulativ-toxischen Wirkung von Aminoglykosiden trotz der Indikationseinschränkungen der gezielte Einsatz von Ciprofloxacin. Eine akute Brucellose kann bei nur diskreten Entzündungswerten und Thrombozytopenie vorliegen. Aufgrund einer langen Inkubationszeit (bis zu 24 Monaten) ist eine ausführliche Reiseanamnese von Bedeutung. Die antibiotische Therapie sollte bei der hohen Resistenz- sowie Rezidivgefahr ausreichend lange und in Kombination erfolgen. Ciprofloxacin stellt aufgrund seiner intrazellulären Wirksamkeit eine Alternative in der Antibiotika-Auswahl für unter 9-Jährige dar, bei denen Tetrazykline nicht eingesetzt werden dürfen.

Invasive Infektionen durch Gruppe B-Streptokokken (Streptococcus agalactiae) und Escherichia coli bei Neugeborenen und jungen Säuglingen - Zwischenergebnisse der ESPED-Studie 2008/2009

F. Lander', B. Heinrich², M. Hufnagel', K. Flügge' ${ }^{1}$, R. von Kries ${ }^{2}$, R. Berner ${ }^{1}$, im Namen der Studiengruppe der ESPED

'Zentrum für Kinder- und Jugendmedizin, Sektion Pädiatrische Infektiologie, Immunologie und Vakzinologie, Universitätsklinikum Freiburg ${ }^{2}$ Erfassungseinheit seltener pädiatrischer Erkrankungen (ESPED) in Deutschland, Koordinierungszentrum für Klinische Studien, Universitätsklinikum Düsseldorf

Hintergrund: Streptokokken der Serogruppe B (GBS) sind die häufigsten Erreger der neonatalen Sepsis und Meningitis. Zwischen 2001 und 2003 wurde in Deutschland die erste ESPED-Studie zur Erfassung der Inzidenz neonataler GBS-Infektionen durchgeführt. In den USA hat die Implementierung einer Screening-basierten intrapartalen Antibiotika-Prophylaxe (IAP) zu einer signifikanten Reduktion der Inzidenz der Early-onset Sepsis durch GBS geführt. Als Folge ist es aufgrund des hohen Selektionsdrucks zu einem Anstieg Antibiotika-resistenter E. coli-Septikämien insbesondere bei Frühgeborenen gekommen. Auch in Deutschland wird die IAP bei bekannter GBS-Kolonisation der Mutter zunehmend angewendet. Zur Veränderung der Inzidenz neonataler Infektionen durch GBS sowie zur Häufigkeit von Infektionen durch E. coli bei Neugeborenen und jungen Säuglingen insbesondere durch Antibiotika-resistente Erreger in Deutschland liegen bisher keine Daten vor. Eine Zwischenauswertung der aktuellen ESPED-Studie nach zwölf Mo- 
naten wird vorgestellt und verglichen mit den Daten der ESPED-Studie 2001-2003.

Methode: Deutschlandweit wurden Erkrankungsfälle durch GBS oder E. coli mit Keimnachweis in Blut oder Liquor bei Neugeborenen und Säuglingen jünger als vier Monate über das Meldesystem der ESPED im Zeitraum von Januar 2008 bis Dezember 2008 erfasst. Von den meldenden Kinderkliniken werden Daten zu Klinik und peripartaler Anamnese mittels Fragebogen erhoben und die über die Kliniklabore eingesandten Erreger-Isolate analysiert.

Vorläufige Ergebnisse: Für das Jahr 2008 wurden bisher 242 Fälle gemeldet, davon konnte zu 202 Fällen ein klinischer Fragebogen erfasst werden (vorläufige Rücklaufquote $83 \%$, Vorstudie $97 \%$ ). 40 Doppel- bzw. Falschmeldungen wurden verworfen. In einer Zwischenauswertung des Zeitraums Januar bis November 2008 traten 101 Infektionen durch GBS auf und damit weniger als im vergleichbaren Zeitraum der Vorläuferstudie mittels des identischen ESPED-Meldesystems erfasst wurden (159 Fälle). Eine Abschätzung, ob tatsächlich ein signifikanter Rückgang der Inzidenz vorliegt, ist bei bislang fehlenden Daten zur Gesamt-Geburtenzahl noch nicht endgültig möglich. Weiterhin wurden insgesamt 44 Infektionen mit E .coli und ein Fall mit Nachweis beider Erreger gemeldet. Dabei wurde Resistenz von E. coli gegenüber Ampicillin in 20 Fällen (45\%) und ein Fall eines ESBL-Bildners (2,2 \%) angegeben. Die GesamtMortalität lag bei 6,2 \% (9 Fälle, davon 7 Kinder mit einem Gestationsalter unter 32 Wochen). Bezüglich der GBS-Infektionen lag die Mortalität bei $6,9 \%$ und somit höher als in der Vorläuferstudie $(4,3 \%)$.

Zusammenfassung: Die Inzidenz von GBS-Infektionen bei Neugeborenen und jungen Säuglingen erscheint im Vergleich zur Vorläuferstudie 2001-2003 rückläufig. Infektionen durch E. coli scheinen weniger als halb so häufig aufzutreten. Dabei finden sich jedoch in relevanter Anzahl Antibiotika-resistente Erreger, so dass bei Bestätigung der Ergebnisse ein Überdenken bisheriger Empfehlungen zur empirischen antibiotischen Therapie der neonatalen Sepsis angebracht erscheint. Ab Januar 2009 wird die noch für ein Jahr weiterlaufende Studie mit einer Doppelerfassung der Fälle über Labormeldungen an das Robert-Koch-Institut ergänzt.

\section{Erreger- und Resistenzspektrum neonataler Sepsis - retrospektive Analyse auf einer neonatologischen Intensivstation L. Dreiser ${ }^{(1)}$, U. Schulze-Sturm ${ }^{(1)}$, M. Klouche ${ }^{(2)}$, J. Runde ${ }^{(1)}$, JH Schwalm $^{(1)}$, G. Selzer ${ }^{(1)}$, HI Huppertz $^{(1)}$ \\ ${ }^{1}$ Prof. Hess-Kinderklinik und Klinik für pädiatrische Intensivmedizin und Neonatologie, Klinikum Bremen Mitte \\ ${ }^{2}$ Bremer Zentrum für Laboratorumsmedizin $\mathrm{GmbH}$}

Hintergrund: Die Sepsis ist eine wichtige Ursache von Morbidität und Mortalität auf neonatologischen Intensivstationen, insbesondere bei kleinen (VLBW; < $1500 \mathrm{~g}$ Geburtsgewicht) und sehr kleinen Frühgeborenen (ELBW; < $1000 \mathrm{~g}$ Geburtsgewicht). Besonders problematisch ist die Gefährdung durch eine nosokomiale, häufig katheterassoziierte Sepsis mit multiresistenten Erregern. Verschiedene Kombinationen von Antibiotika werden je nach klinikspezifischem Erregerspektrum angewendet.

Methode:Um einen Überblick über das lokale Erreger- und Resistenzspektrum zu gewinnen, führten wir eine retrospektive Analyse aller neonatalen Sepsisfälle in den Jahren 2007 und 2008 auf unseren beiden Intensivstationen durch. In die Untersuchung eingeschlossen wurden alle Neugeborenen bis ET+ 28 Tage. Alle Fälle, die nach einem Lebensalter von 72 Stunden auftraten, wurden als nosokomiale Sepsis gewertet.

Ergebnisse: Bei einer Gesamtzahl von 496 Patienten, davon 154 VLBW bzw. ELBW, erkrankten 85 Patienten an insgesamt 97 Sepsis-Episoden, davon 64 Fälle bei VLBW bzw. ELBW. Von einer nosokomialen Sepsis (Erkrankungsalter $>72 \mathrm{~h}$ ) waren 33 Kinder betroffen, davon 30 mit Geburtsgewicht $<1500$ g (Inzidenz $19 \%$ ). An einer konnatalen Sepsis erkrankten insgesamt 52 Patienten. Die am häufigsten isolierten Erreger waren koagulasenegative Staphylokokken (CoNS, 20\%) und gramnegative Stäbchen (19\%). Wir konnten eine Zunahme an Infektionen mit
CoNS in $2008(n=15)$ im Vergleich zum Vorjahr $(n=5)$ zeigen, betroffen waren insbesondere Kinder mit einem Geburtsgewicht unter 1000 g. Alle CoNS waren oxacillinresistent. Unter den gramnegativen Stäbchen fanden sich zahlreiche multiresistente E. coli und Klebsiellen, sowie Enterobacter. Gegenüber der von uns als first line Therapie eingesetzten Kombination Ampicillin/Gentamicin waren innerhalb der ersten 72 Lebensstunden alle Erreger sensibel; im Zeitraum danach zeigten 2/3 Resistenzen. Gegenüber der von uns ab einem Alter von 2 Wochen verwendeten Kombination Flucloxacillin/Cefotaxim fand sich eine weit überwiegende Zahl von resistenten Erregern, z.T. schon innerhalb der ersten 72 Lebensstunden.

Diskussion: Die hohe Zahl an cefotaximresistenten Erregern (teilweise bereits Erkrankungsbeginn $<72 \mathrm{~h}$ ) wird vermutlich durch die pränatale Anwendung von Antibiotika selektioniert. Trotz der nachgewiesenen Oxacillinresistenz der CoNS war klinisch in einigen Fällen ein Ansprechen auf die Therapie mit Flucloxacillin und Cefotaxim festzustellen, was möglicherweise auf eine Diskrepanz zwischen in vitro-Testung und in vivo-Wirksamkeit zurückzuführen ist. Die Zunahme von Infektionen durch CoNS 2008 konnte durch Erregertypisierung und Umgebungsanalyse aufgeklärt und durch veränderte Hygienemaßnahmen gestoppt werden. Dennoch sollten antibiotische Regimes kontinuierlich überprüft und an das lokale Erreger- und Resistenzspektrum angepasst werden.

Ausbrüche durch Serratia marcescens auf neonatologischen und pädiatrischen Intensivstationen

A.Völz, J. Gillen, T.Dresbach, A.Müller, A. Simon

Pädiatrische Infektiologie, Zentrum für Kinderheilkunde am Universitätsklinikum Bonn

Serratia marcescens ist ein gramnegativer Erreger nosokomialer Infektionen (Sepsis, Meningitis, Harnwegs- und Wund-infektionen, Konjunktivitis), der häufig als Auslöser nosokomialer Ausbrüche beschrieben wurde. Ausgehend von einer systematischen Analyse von 25 Studien, in denen der Ausbruch durch Genotypisierung gesichert wurde, wird die Epidemiologie (Infektionsrate, Übertragungswege, Vektoren und Reservoire), Risikofaktoren, klinische Krankheitsbilder und die Letalität von S.marcescens Ausbrüchen auf neonatologischen und pädiatrischen Intensivstationen beschrieben. Insgesamt waren in die publizierten Ausbrüche 529 Kinder involviert. Die mediane Infektionsrate (Anteil der Kinder mit Infektion unter allen Kindern mit pos. Nachweis) lag bei $51 \%$. Die mediane Letalität lag bei 6\% (0-50\%). 14-mal wurde der Erreger auf den Händen von medizinischem Personal nachgewiesen. S. marcescens ist ein hochpathogener Erreger von NI; die Eindämmung der nosokomialen Übertragung erfordert ein zeitnah implementiertes, interdisziplinäres Multibarrierekonzept und ggfls. auch die vorübergehende Schließung der betroffenen Intensivstation.

\section{Nekrotisierende Pneumonie durch Pneumokokken}

A. Lieb, J. Schulze, M. Rosewich, M. Christmann, MA. Rose, S. Zielen Zentrum für Kinder- und Jugendmedizin, J.W. Goethe-Universität Frankfurt am Main

Einleitung: Die nekrotisierende Pneumonie im Kindesalter ist gekennzeichnet durch eine massive Nekrose von Lungengewebe. Ursächlich ist in der Regel eine Infektionen mit Pneumokokken. Charakteristisch sind frühe Veränderungen im CT-Thorax mit einer Retraktion des Lungengewebes sowie eines homogenen Randsaumes. Im Verlauf kommt es unter der Bildung von Kavitäten zu einer Auflösung des Exsudates.

Fallbeschreibung 1: Ein knapp 6 Jahre alter Junge mit seit 6 Tagen bestehendem Fieber und Husten, trotz der Therapie mit Azithromycin. Klinisch Bild einer Pneumonie, im Röntgen Thorax vollständig weiße Lunge links, im CT-Thorax charakteristische Veränderungen einer nekrotisierenden Pneumonie. Therapie mit Cefuroxim iv für 21 Tage, darunter nach 7 Tagen Entfieberung. Nachweis von S. pneumoniae in der Blutkultur, die Serologie für sieben Pneumokokken Serotypen war 
negativ. Fall 2: Ein knapp 5 Jahre alter Junge mit Fieber seit 4 Tagen. Im Röntgen Befund einer Unterlappenpneumonie links. Unter der Therapie mit Cefuroxim zunächst Besserung. Bei zunehmender Dyspnoe und erneut abgeschwächtem Atemgeräusch am 6. stationären Tag Kontrolle des Röntgen, nun fast komplette Verschattung der linken Lunge. Im CTThorax Veränderungen einer nekrotisierenden Pneumonie. Am 13. Tag der Behandlung Auffiebern, zusätzliche Therapie mit Meropenem. In der Folge Verschlechterung mit erneut deutlich abgeschwächtem Atemgeräusch. Nun kompletter Pneumothorax der linken Lunge mit basalem Erguss. Es erfolgte eine Pleuradrainage. Weder in der Blutkultur noch im Pleurapunktat konnten Erreger nachgewiesen werden. Die Serologie für die Pneumokokken zeigte keinen Schutz für 5 Serotypen. Die Gesamtdauer der antibiotischen Therapie betrug 28 Tage.

Schlussfolgerung: Das Wichtigste ist die Diagnosestellung der nekrotisierenden Pneumonie mit Hilfe der CT-Thorax. Mögliche Komplikationen sind Pleuraergüsse und in seltenen Fällen ein Pneumothorax. Eine thoraxchirurgische Intervention ist in der Regel nicht notwendig.

\section{Untersuchung einer Korrelation zwischen klinischen Charakteristika einer stationär behandelten obstruktiven Bronchitis oder Pneumonie bei Kindern und dem nachgewiesenen Virustyp und Viruslast A.Franz, R.Willems, L.Bonzel, O.Adams, H.Schroten, T.Tenenbaum Klinik für allgemeine Pädiatrie des Zentrums für Kinderheilkunde und Jugendmedizin der Universitätsklinik Düsseldorf, Institut für Virologie der Universitätsklinik Düsseldorf, Universitätskinderklinik Mannheim}

Fragestellung: Gibt es einen Zusammenhang zwischen dem nachgewiesenen Virustyp oder der nachgewiesenen Viruslast im nasopharyngealen Aspirat (NPA) und den klinischen Charakteristika einer Infektion bei Kindern, die aufgrund einer obstruktiven Bronchitis oder Pneumonie stationär behandelt wurden?

Methode: Prospektive epidemiologische Studie an Kindern zwischen 0-16 Jahren zwischen November 2006-Oktober 2008. NPAs wurden am Tag der Aufnahme (1.NPA) und am 3./4. stationären Tag (2. NPA) entnommen und mittels eines quantitativen Multiplex RT-PCRs auf respiratorische Viren (RSV A und B, Rhinoviren, Adenoviren, Bocaviren, Influenza A und B, Parainfluenza 1,2 und 3, HMPV A und B, Enteroviren und Coronaviren $229 \mathrm{E}, \mathrm{OC} 43$ und NL63) untersucht. Parallel erfolgte eine Erhebung von klinischen und laborchemischen Parametern der Krankheitsschwere.

Ergebnisse: 404 Kinder wurden erfasst, von denen 244 aufgrund einer obstruktiven Bronchitis und 160 aufgrund einer Pneumonie stationär behandelt wurden. Bei $78 \%$ der Kinder wurde mindestens ein viraler Erreger nachgewiesen. Koinfektionen mit mindestens 2 Erregern wurden in 67 Fällen $(16,7 \%)$ gefunden. Eine zweite NPA konnte bei $70,5 \%$ der Kinder untersucht werden. Am häufigsten wurde RSV (160 Fälle, 50,8\%) gefolgt von Rhinovirus ( 83 Fälle, 26,3\%) und Bocavirus und Adenovirus (je 28 Fälle, 8,9\%) nachgewiesen. 54 der Fälle waren Monoinfektionen mit Rhinovirus. Die Kinder, bei denen eine Rhinovirus-Monoinfektion nachgewiesen wurde, waren im Vergleich zu den Kindern mit einer RSV-Monoinfektion jünger (Altersmedian 1,4 Jahre vs. 0,5 Jahre) und eher männlich ( $65 \%$ vs. $55 \%$ ). Die mittlere Liegedauer bei RSV-Monoinfektion betrug 5,7 Tage vs. 4,9 Tage bei einer Rhinovirus-Monoinfektion. Der Vergleich von RSV-Koinfektionen und RSV-Monoinfektionen zeigte einen häufigeren Einsatz von Antibiotika (64\% vs. $41 \%$ ), häufigere Verordnung eines Röntgen-Thorax (55\% vs. $42 \%$ ) und häufigeres Auftreten von Fieber ( $71 \%$ vs. $60 \%$ ) bei RSV-Koinfektionen. Der Viruslastvergleich zwischen der 1. und 2. NPA zeigte bei RSV und Adenoviren einen medianen Abfall von mehr als einer log-Stufe. Dagegen fiel der Unterschied bei Rhino- und Bocaviren deutlich flacher aus.

Schlussfolgerung: Die klinischen Charakteristika einer Infektion mit respiratorischen Viren scheinen sowohl vom Virustyp wie auch von der Viruslast und Anzahl der nachgewiesenen Erreger abhängig zu sein. Rhinoviren spielen als Erreger von Infektionen des unteren Respirationstraktes eine bedeutende Rolle.
Polyomavirus Ki und Wu bei Kindern mit akuter Atemwegsinfektion A.Müller, A.Simon, J.Gillen, V.Schildgen, RL Tillmann, K.Reiter, O.Schildgen Pädiatrische Infektiologie und Virologie, Universitätsklinikum Bonn

Einleitung: Seit dem Jahr 2001 wurden eine Reihe „neuer“ respiratorischer Viren beschrieben. Hierzu zählen die kürzlich entdeckten Polyomaviren $\mathrm{Ki}(\mathrm{KIPyV})$ und $\mathrm{Wu}(\mathrm{WUPyV})$. Wir untersuchten die Prävalenz dieser Viren bei Kindern mit Infektionen der Atemwege.

Material und Methode: Von 229 Kindern mit akuter Atemwegsinfektion wurde nasopharygeales Sekret prospektiv auf RSV, Influenza viruses A/B, Coronavirus (NL63, HKU1, OC43, 229E), Rhinovirus, Adenovirus, hMPV und hBoV mittels PCR oder RT-PCR untersucht. Retrospektiv wurden alle Proben auf Polyomavirus KI und Wu DNA mit PCR untersucht.

Ergebnisse: Polyomavirus DNA wurde in 3 (1.3\%) von 229 Patienten gefunden. Co- Infektion mit anderen respiratorischen Viren konnten bei diesen 3 Patienten nicht nachgewiesen werden. KIPyV DNA wurde bei 2 Patienten gefunden. Ein 4 Jahre altes Mädchen litt im Rahmen der Erstmanifestation eines Diabetes mellitus an einem fieberhaften Infekt der oberen Luftwege der ohne Therapie bis zum Entlassungstag (Tag 12) ausheilte. Die zweite Patientin mit akuter myeloischer Leukämie und Knochenmarkstransplanation (KMT) zeigte am Tag 37 nach KMT Zeichen eines akuten Atemwegsinfektes mit radiologischem Nachweis einer linksseitigen basalen Pneumonie, die sich unter antibiotischer Therapie in den folgenden 3 Wochen zurückbildeten. Bei einer Patientin mit akuter obstruktiver Bronchitis wurde WUPyV DNA nachgewiesen. Die Symptome dieser 2,5 Jahre alten Patientin sistierten unter bronchodilatativer Therapie bis zur Entlassung am Tag 5.

Schlussfolgerung: In unserem Patientenkollektiv zeigte sich mit 1.3\% eine niedrige Prävalenz für die neuen Polyomaviren Ki und Wu. Andere Prävalenzstudien zeigen eine höhere Rate von Infektionen mit diesen Viren, wobei im Gegensatz zu unseren Patienten bei bis zu 75\% der Patienten Co- Infektionen mit anderen respiratorischen Viren nachgewiesen. Die klinische Relevanz KIPyV und WUPyV als Erreger von Infektionen der Atemwege bleibt somit weiter offen. Zusätzlich müssen weitere Studien klären, ob KIPyV und WUPyV, wie bei anderen humanen Polyomaviren bekannt, im Körper persistieren und reaktiviert werden können und ob sie über ein onkogenes Potential verfügen.

Ein Komplementdefekt als mögliche Ursache rezidivierender invasiver Pneumokokkeninfektionen (IP)

J Möller ${ }^{(1)}$, FH Hauck ${ }^{(1)}$, JL Casanova ${ }^{(2)}$, R Roesler ${ }^{(1)}$

1) Immunologische Ambulanz, Klinik und Poliklinik für Kinder- und Jugendmedizin, Universitätsklinikum CG Carus, Dresden ${ }^{2}$ ) Laboratoire de Génétique Humaine des Maladies Infectieuses, Institut National de la Santé et de la Recherche Médical, Paris

Fragestellung: IP können zu Defektheilungen oder tödlichem Ausgang führen. Verschiedene anatomische Störungen und primäre Immundefekte (PID) gehen mit erhöhter Suszeptibilität für IP einher, entziehen sich jedoch teilweise der Routinediagnostik. Das differenzialdiagnostische Vorgehen und eine sich anschließende Prophylaxe werden im Folgenden erörtert.

Material und Methoden: Infektiologischer Fallbericht mit immunologischer Differenzialdiagnostik. Ergebnisse: Die Patientin erkrankte mit 1 8/12 Jahren an Meningitis und Sepsis durch S. pneumoniae, so dass eine dreiwöchige Intensivbehandlung notwendig wurde. Aufgrund einer resultierenden Innenohrschwerhörigkeit beidseits wurde sie mit Cochleaimplantaten versorgt. Die behandelnden Ärzte waren der Meinung, dass Kleinkind wäre nun immun gegen S. pneumoniae, so dass trotz Anfrage der Mutter keine Pneumokokkenimpfung erfolgte. Mit 3 5/12 Jahren erkrankte die Patientin erneut an Meningitis und Sepsis durch S. pneumoniae, so dass sie wiederum intensivmedizinisch behandelt werden musste. In der anschließenden neurologischen Rehabilitation scheiterte eine kranielle CT in Sedierung, weshalb die Patientin zur Bildgebung in Narkose in unsere Klinik überwiesen wurde. In der Eigen- und Fami- 
lienanamnese fanden sich keine weiteren ungewöhnlichen Infektionen, Autoimmunphänomene oder Erkrankungen. In der Zweitbefundung der präoperativen CT- und MRT-Bildgebung sahen wir keine knöchernen oder anderweitige Strukturdefekte und keine Liquorfistelung. Sonographisch und hämatologisch schlossen wir eine anatomische oder funktionelle Asplenie aus. Das adaptive zelluläre und das adaptive humorale Immunsystem waren unauffällig, insbesondere konnten Impfantikörper gegen Polysaccharidantigene gebildet werden. Wiederholt fanden wir eine stark erniedrigte Aktivität der klassischen Komplementkaskade $\left(\mathrm{CH}_{50}\right)$ bei intaktem alternativen Komplementweg. Eine quantitative Messung der Komplementfaktoren $\mathrm{C}_{3}$ und $\mathrm{C}_{4}$ war unauffällig, $\mathrm{C}_{2}$ war leicht erniedrigt. Aktuell steht die funktionelle Einzelfaktorenanalytik aus. Eine in vitro Analyse der Aktivierung peripherer Leukozyten wies auf eine fehlende IL-10-Produktion nach Stimulation mit TNF- $\alpha$ hin, so dass auch ein Defekt des NF- $\kappa B-S i g n a l w e g e s ~ d e n k b a r$ wäre. Allerdings sprechen die physiologischen Akute-Phase-Reaktionen während der IP eher gegen einen solchen Defekt. Trotz einer berichteten Ampicillin-Allergie begannen wir eine Penicillin-Prophylaxe und führten die ausstehenden Impfungen gegen Pneumo- und Meningokokken durch. Bisher sind weder Nebenwirkungen noch erneute IP aufgetreten.

Schlussfolgerungen: Der Wissensstand über die Differenzialdiagnostik und Prophylaxe der IP ist teilweise unzureichend. Zur Vermeidung schwerer Krankheitsverläufe muss die Kooperation der verschiedenen Fachrichtungen mit den pädiatrischen Immunologen verbessert werden. Ein erweitertes Verständnis der angeborenen Immunität durch Forschungsarbeit könnte zur besseren Erfassung der Disposition zur IP beitragen.

\section{Invasive Pneumokokken-Erkrankungen bei Erwachsenen in Deutsch- land - Mögliche Herdenimmunitätseffekte nach Einführung der Pneu- mokokken-Konjugatimpfung bei Kindern}

M. Imöhl, RR Reinert, M. v. d.Linden

Nationales Referenzzentrum für Streptokokken und Institut für Medizinische Mikrobiologie, RWTH-Aachen, Deutschland

Streptococcus pneumoniae ist eine der häufigsten Ursachen von Pneumonie, Sepsis und Meningitis in Deutschland. Insbesondere junge Kinder und ältere Erwachsene sind hiervon betroffen. Nachdem im Juli 2006 eine generelle Impfempfehlung für alle Kinder bis zum Alter von 24 Monaten mit einem Pneumokokken-Konjugatimpfstoff von der Ständigen Impfkommissiom am Robert-Koch-Institut (STIKO) ausgesprochen wurde, begann das Impfprogramm im Januar 2007 in allen Bundesländern (in Sachsen bereits ein Jahr eher). Hier zeigen wir die Auswirkungen der Impfung bei diesen Kindern auf die Zahl invasiver Pneumokokkenerkrankungen bei Erwachsenen (HerdenimmunitätsEffekt). Das nationale Referenzzentrum für Streptokokken (NRZS) führt seit 1992 Studien zu invasiven Pneumokokkenerkrankungen bei Erwachsenen durch. Entsprechende invasive Isolate werden von 265 medizinischen Laboratorien in ganz Deutschland im Rahmen eines labor-basierten Surveillance-Systems ans NRZS gesandt. Für drei Bundesländer (Nordrhein-Westfalen seit 2001, Bayern und Sachsen seit 2006) besteht ein populations-basiertes Meldesystem. Seit Januar 2007 besteht darüber hinaus auch ein web-basiertes bundesweites Surveillance-System. Die aktuelle Analyse beinhaltet Fälle von 2002-2009. Die Spezies-Bestimmung erfolgte unter anderem mittels Prüfung der OptochinEmpfindlichkeit sowie der Gallelöslichkeit. Die Serotypisierung erfolgte durch die Neufeld'sche Quellungsreaktion. Analog zu der verbesserten Surveillance stieg die Anzahl der gemeldeten Fälle und eingesandten Isolate von 421 im Pneumokokkenjahr 2003-2004 auf $1761 \mathrm{im} \mathrm{Jahr}$ 2007-2008. Da in Deutschland keine Meldepflicht für invasive Pneumokokkenerkrankungen besteht, ist eine zuverlässige Aussage über die Inzidenz nicht möglich. Es zeigt sich jedoch ein Abfall des Anteils invasiver Pneumokokkenerkrankungen durch Impfstoff-Serotypen, was als Impfstoff-Effekt zu deuten sein dürfte. Von 2002 bis 2006 lag der Anteil der Impfstoff-Serotypen zwischen $42.9 \%$ und 48.5\%, im Jahr 2007-2008 nur noch bei $33.4 \%$. Die drei populationsbasierten Studien zeigten ana- loge Ergebnisse. Ein 13-valenter Pneumokokken Konjugatimpfstoff ist auch für Erwachsene in der Entwicklung und hätte in 2007-2008 72.9\% der invasiven Pneumokokkenerkrankungen in Deutschland abgedeckt. Seit Bestehen der generellen Impfempfehlung für die PneumokokkenKonjugatimpfung ist es zu einer deutlichen Verminderung invasiver Pneumokokkenerkrankungen bei Kindern unter 2 Jahren gekommen. Darüber hinaus zeigen die hier beschriebenen Ergebnisse einen Rückgang des Anteils von Impfstoff-Serotypen an den invasiven Pneumokokkenerkrankungen bei Erwachsenen. Dies könnte auf einen Herdenimmunitätseffekt hinweisen.

Epidemiologie invasiver Pneumokokkenerkrankungen bei Kindern in Deutschland von 1997-2009, Effekte der Einführung der Pneumokokken-Konjugatimpfung

M. Imöhl(1), M. v.d. Linden ${ }^{(1)}$, R. v. Kries ${ }^{(2)}$, A. Siedler ${ }^{(3)}$, RR. Reinert ${ }^{(1)}$, S. Rückinger ${ }^{(2)}$

${ }^{1}$ NRZ für Streptokokken und Institut für Medizinische Mikrobiologie, RWTH-Aachen ${ }^{2}$ Institut für Soziale Pädiatrie und Jugendmedizin, Abteilung für Epidemiologie im Kindes- und Jugendalter, LMU München ${ }^{3}$ Abteilung für Infektionsepidemiologie, RKI, Berlin

Streptococcus pneumoniae ist eine der häufigsten Ursachen von Pneumonie, Sepsis und Meningitis in Deutschland. Insbesondere junge Kinder und ältere Erwachsene sind hiervon betroffen. Nachdem im Juli 2006 eine generelle Impfempfehlung für alle Kinder bis zum Alter von 24 Monaten mit einem Pneumokokken-Konjugatimpfstoff von der Ständigen Impfkommissiom am Robert-Koch-Institut (STIKO) ausgesprochen wurde, begann das Impfprogramm im Januar 2007 in allen Bundesländern (in Sachsen bereits ein Jahr eher). Hier zeigen wir Änderungen in der Zahl invasiver Pneumokokkenerkrankungen nach Einführung der Impfung. Seit 1997 sammelt das nationale Referenzzentrum für Streptokokken (NRZS), in Zusammenarbeit mit dem Robert Koch Institut (RKI), Isolate invasiver Pneumokokkenerkrankungen (IPE) bei Kindern. Eine Serotypisierung erfolgte durch die Neufeld'sche Quellungsreaktion. IPE sind in Deutschland nicht meldepflichtig. Die Erhebungseinheit für Seltene Pädiatrische Erkrankungen in Deutschland (ESPED) erhebt IPE Fälle in Kinderkrankenhäusern, während das RKI anhand derselben Falldefinition in mikrobiologischen Labors Fälle erhebt. Auf Basis dieser zwei Melde-Quellen wurde eine Capture Recapture Analyse durchgeführt um auf tatsächliche Erkrankungszahlen zu schließen. Bei Kindern unter zwei Jahren, konnte seit Einführung der Impfung ein Rückgang um $50 \%$ der eingesendeten Isolate an das NRZS verzeichnet werden. Dieser Zahl konnte durch die Capture Recapture Analyse bestätigt werden: Die Inzidenz pro 100.000 bei Kindern unter zwei Jahren ging von 20.0 zurück auf 10.9. Der Rückgang wurde bei allen im Impfstoff enthaltenen Serotypen wahrgenommen, am stärksten bei den Serotypen 14 und ${ }_{23}$ F. Bei den nicht im Impfstoff entaltenen Serotypen wurden keine signifikanten Veränderungen in der Häufigkeit in dieser Altersgruppe beobachtet. In den Altergruppen 2 bis 4 Jahre und 5 bis 15 Jahre konnte kein Rückgang der IPE Inzidenz verzeichnet werden

Pneumokokkenperikarditis mit hämolytisch-urämischem Syndrom: Ist eine immunologische Abklärung sinnvoll?

S. Kenzel $\left({ }^{1}, 2\right)$, H. Fehrenbach ${ }^{(3)}$, M.Pohl ${ }^{(1)}$, P. Henneke $\left({ }^{1},{ }^{2}\right)$

${ }^{1}$ Zentrum für Kinderheilkunde und Jugendmedizin, Universitätsklinik Freiburg, Deutschland ${ }^{2}$ Centrum für chronische Immundefizienz, Universitätsklinik Freiburg, Deutschland ${ }^{3}$ Kinderklinik Memmingen, Deutschland

Streptococcus pneumoniae ist die häufigste Ursache für bakterielle Otitiden, Pneumonien und Sepsis im Kindesalter. Wir berichten hier über ein 20 Monate altes Mädchen, das mit Sepsis, Pneumokokkenperikarditis und hämolytisch-urämischem Syndrom einen besonders schweren Verlauf einer invasiven Pneumokokkeninfektion präsentierte. In der Blutkultur ließ sich S. pneumoniae des Serotyp 14 nachweisen. Das Mädchen war bis zu diesem Zeitpunkt stets gesund und abgesehen von ei- 
ner fehlenden Pneumokokkenimmunisierung vollständig entsprechend der STIKO-Empfehlungen geimpft. Trotz adäquater i.v.-antibiotischen Therapie mit Vancomycin und Cefotaxim war eine intermittierende Hämodialyse und die Anlage einer Perikarddrainage erforderlich. Eine PCR für Pneumolysin, einem spezifischen Toxin von S. pneumoniae, an Perikardflüssigkeit war positiv. Im Verlauf kam es ohne weitere Komplikationen zu einer vollständigen Genesung ohne wesentliche Residuen. Dieser Fall zeigt, dass eine invasive Pneumokokkeninfektion (IPD) sich in nahezu jedem Organ manifestieren kann. Daher muss selbst bei Fehlen von Symptomen im Bereich des Respirationstraktes auch bei einem hämolytisch-urämischen Syndrom oder purulenter Perikarditis an eine systemische Infektion durch Pneumokokken gedacht werden. Aktuelle Forschungsberichte präsentieren in steigender Zahl definierte monogene Proteindefekte (z.B. Mutationen in IRAK-4, NEMO oder TNF), die zelluäre Signalkaskaden des Immunsystems derart beeinflussen, so dass es zu einer deutlich erhöhten Anfälligkeit für invasive Infektionen kommt. Die populationsbezogene Epidemiologie schwerer Pneumokokkeninfektionen ist weiterhin unklar. Daher scheint es wichtig, ein strukturiertes immunologisches „Workup“ für Patienten mit ungewöhnlichem oder rekurrentem Krankheitsverlauf zu etablieren.

\section{Parechovirus 3 Sepsis und Enzephalitis bei einem Neugeborenen} A. Müller, AM Eis-Hübinger, J. Schmitt, S.Vollbach, A. Simon, M.Panning Neonatologie, Pädiatrische Infektiologie und Virologie des Universitätsklinikum Bonn

Einleitung: Während die humanen Parechovirus (HPeV) 1 und 2 milden gastrointestinale oder respiratorische Symptome verursachen, ist $\mathrm{HPeV}_{3}$, erstmals 2004 beschrieben, mit sepsis-ähnlichen Krankheitsbildern assoziiert. Wir beschreiben ein Neugeborenes mit Sepsis und Enzephaltis verursacht durch $\mathrm{HPeV} 3$.

Fallbeschreibung: Ein 4 Wochen altes ehemaliges Frühgeborenes der 33. SSW wurde in reduzierten Allgemeinzustand, Trinkschwäche und Hypothermie in der Notaufnahme vorgestellt. Es erfolgte die Aufnahme auf der Intensivstation und die sofortige antibiotische Behandlung (Cefotaxim/Ampicillin/Sulbactam/Tobramycin) ergänzt durch Acyclovir bei auffallender Vigilanzstörung. Am 2. stationären Tag wurde der Patient bei Apnoen und Kreislaufinsuffizienz intubiert, beatmet und benötigte Kreislaufunterstützung mit Volumen und Katecholaminen. Blut-, Urinund Liquorkultur zeigten kein Wachstum. Molekularbiologische Untersuchungen des Trachealsekrets und des Liquors auf die bekannten respiratorischen und neurotropen Viren (einschließlich Enteroviren) waren negativ. Am 7. stationären Tag bestand der Verdacht auf eine HPeV Infektion so dass erneut eine LP durchgeführt wurde. Real-Time PCR Untersuchungen auf HPeV 1-6 im Blut, Liquor, Trachealsekret und Stuhl waren positiv. Die Genotypisierung durch Sequenzierung der VP1 Region zeigte $\mathrm{HPeV}_{3}$. Im Liquor wurden 2X105 RNA Kopien/ml, im Tracheal- bzw. Rachensekret 1x107 RNA Kopien/ml am 4. stationären Tag und 4x104 RNA Kopien/ml am 10. stationären Tag gemessen. Virusausscheidung im Stuhl konnte über 1o Tage gemessen werden. Nach 3 Tagen Kreislaufunterstützung und 7 Tagen Beatmung stabilisierte sich der Patient und konnte am 21. stationären Tag nach Hause entlassen werden. Eine MRT Untersuchung des Gehirns 2 Tage vor Entlassung zeigte kleine Blutungen rechts frontal und temporal sowie postentzündliche Veränderungen links frontal.

Diskussion: HPeV können bei Neugeborenen schwere sepsisähnliche Krankheitsbilder mit Enzephalitis verursachen und sollten bei der Diagnostik berücksichtigt werden.

\section{Meningitis durch Varizella-Zoster-Viren}

T. Hartmann, P.v.Blanckenburg

Klinik für Kinder- und Jugendmedizin, Kreiskrankenhaus Hameln

Fallvorstellung: 13 11/12 Jahre alter Junge, stationäre Aufnahme bei klinischen Zeichen einer Meningitis. 3 Tage vor der stationären Aufnahme Entwicklung eines Herpes Zoster. Knapp 9 Jahre zuvor deutlich ausgeprägte
Varizelleninfektion. Bei Aufnahme Herpes-Zoster-Effloreszenzen rechts Dermatom Th 11/12, diffuser Haarausfall, ausgeprägter Meningismus, sonstiger Untersuchungsbefund unauffällig. Laborchemisch zeigten sich unauffällige systemische Infektparameter, die Lumbalpunktion ergab eine lymphomonozytäre Meningitis. Nachweis von VZV-AK IgG in Serum und Liquor, sowie positive VZV-PCR im Liquor. Im EEG zeigten sich geringe fokale Störungen, das MRT war unauffällig. Wir behandelten den Patienten über 14 Tage mit Aciclovir (3 x 10 mg/kg KG/d). Rasche Besserung der meningealen Symptomatik und Abheilung der Effloreszenzen. Nebenbefundlich bei diffusem Haarausfall Diagnose eines mäßiggradigen Zinkmangels. Fazit: Reaktivierte VZV-Infektionen als Ursache einer Meningo-Enzephalitis sind bislang in der Literatur sowohl bei immungesunden Erwachsenen, als auch in der Pädiatrie selten beschrieben. Auch nach erfolgter Varizellenimpfung besteht ein Zosterrisiko, in der Regel aber seltener und mit milderem Verlauf. Sowohl bei Geimpften, als auch bei vorangegengener VZV-Infektion kann die Meningoenzephalitis ohne das typische Exanthem einhergehen und sollte daher als Auslöser einer aseptischen Meningitis in Betracht gezogen werden. In diesem Zusammenhang stellt sich die Frage, ob eine seröse Meningitis in jedem Fall bis zum Ausschluß einer meningealen VZV-Infektion mit Aciclovir behandelt werden muß.

Fieber ohne Fokus: FSME ohne Meningoencephalitis

PM Meyer, R. Guggenheim, P.Goetschel

Klinik für Kinder und Jugendliche Stadtspital, Triemli, Zürich

Hintergrund: Kinder mit Status febrilis ohne erkennbare Ursache in der klinischen Untersuchung sind ein häufiges Problem auf der Notfallstation. Die Routineuntersuchungen umfassen eine Urinuntersuchung und ein Thoraxröntgenbild. Die Lumbalpunktion wird bei älteren Kindern in der Regel nur bei klinischem Verdacht auf eine Meningoencephalitis durchgeführt. FSME wird bei Patienten mit Fieber und Zeichen einer Meningitis und Enzephalitis diagnostiziert. Die Diagnose FSME kann aber auch erhoben werden, wenn eine Lumbalpunktion und Blutserologie beim Fehlen jeglicher meningitischen Zeichen durchgeführt wird.

Methodik: Anhand der Krankengeschichten aus den Jahren 2000 bis 2008 wurden Patienten mit FSME identifiziert (ICD-10: A84.1). Es erfolgte eine Analyse derjenigen Patienten, die sich initial nur mit Fieber präsentierten.

Ergebnisse: Wir haben 4 Patienten mit Fieber ohne klinischen Fokus und serologisch nachgewiesener FSME-Infektion beobachtet. Es waren 3 Knaben und 1 Mädchen im Alter von 4 bis 9 J. (Median 5.8). Alle Patienten präsentierten sich mit Fieber $\left(38.5\right.$ bis $\left.40.0^{\circ} \mathrm{C}\right)$. Anamnestisch war dies jeweils die zweite Fieberepisode nach einem freien Intervall. Der Allgemeinzustand war leicht- bis mittelgradig reduziert und die Patienten klagten über Kopfschmerzen. 3 Patienten hatten zusätzlich Erbrechen. Der Neurostatus war normal, insbesondere waren alle meningitischen Zeichen negativ. Eine Urinuntersuchung wurde bei allen Patienten, ein Thoraxröntgenbild bei 2 Patienten durchgeführt. Zur weiteren Abklärung erfolgte eine Lumbalpunktion. Diese zeigte eine seröse Meningitis (Gesamtzellzahl 67 - 164/ $\mu$ l, davon Mononukleäre 27 - 57\%; Protein 304 - 577 mg/l, Glukose 2.9 - $4.1 \mathrm{mmol} / \mathrm{l})$. Bakteriologische Kulturen waren steril. Im Blut fand man erhöhte Entzündungszeichen (Leukozyten 11.9 - 34.5 G/l, CRP 3 - 69.7 mg/l). Die Diagnose FSME wurde serologisch bestätigt, alle Patienten hatten in der KBR positive IgM- und IgG-Titer. Schlussfolgerung: Bei Kindern kann sich die FSME ausschliesslich mit einem Status febrilis, reduziertem Allgemeinzustand und Kopfschmerzen manifestieren („grippaler Infekt“). Zur Diagnosestellung muss deshalb eine Lumbalpunktion durchgeführt werden, auch wenn keine klinischen Zeichen der Meningoenzephalitis vorhanden sind. Beim Nachweis einer Liquor-Pleozytose sollte die FSME mittels Bestimmung der Serologie im Blut immer gesucht werden. Bei Bestätigung der Diagnose kann auf weitere Abklärungen verzichtet werden. Die FSME ist in der Schweiz eine meldepflichtige Infektionskrankheit. Unsere Empfehlung zur Abklärung febriler Kinder würde auch zur Erhöhung der gemeldeten Inzidenz von FSME beitragen. 
Lymphom-verdächtige Zellen im Liquor und MRT Veränderungen- Pitfall in der Diagnostik der Neuroborreliose

T.Dresbach, J. Gillen, H. Zillhardt, A.Müller, A. Simon

Pädiatrische Infektiologie, Zentrum für Kinderheilkunde am Universitätsklinikum Bonn

Wir berichten über eine Patientin, die seit einigen Monaten über intermittierende Kopfschmerzen klagte und nach einem Bagatelltrauma im Halsbereich Cephalgien, Übelkeit, Erbrechen und Gesichtsfeldausfälle angab. In den letzten 2 Monaten hatte die Patientin 10\% ihres Körpergewichts verloren. In der Kontrast-MRT zeigte sich in den T2 gewichteten Sequenzen eine Signalanhebung des Myelons auf Höhe der Wirbelkörper HWK 3 und 4 . Im Liquor fand sich eine Pleozytose (88 Zellen/ $\mu$ l) mit mäßig erhöhtem Liquoreiweiß $(86 \mathrm{mg} / \mathrm{dl})$. In der Liquorzytologie fanden sich Tumorzell-verdächtige Zellen, die zur Verdachtsdiagnose eines B-Zell-Lymphoms des zentralen Nervensystems führten (CD19/ $\mathrm{CD}_{20} / \mathrm{CD}_{22} / \mathrm{CD} 45$ positiv, $\mathrm{CD}_{5} 6$ negativ). In der Knochenmarkspunktion fand sich eine Erhöhung der B-lymphatischer Progenitorzellen mit c-ALL-Typ im Knochenmark (CD10+, CD19+, CD79a+, Cd22+, CD20 neg., IgM neg, IgGneg; $1,2 \%$ der WBC und $28 \%$ der B-Zellen). Aus differentialdiagnostischen Erwägungen wurde eine Borrelien-Serologie durchgeführt, die ein positives Ergebnis ergab (Serum und Liquor ELISA positiv für Borrelien IgG und IgM, bestätigt im Westernblot). Daraufhin wurde eine 14-tägige, ambulant durchgeführte Therapie mit Ceftriaxon eingeleitet. Anschließend erhielt die Patientin noch für 7 Tage Doxycyclin po. Hierunter kam es zu einer vollständigern Heilung der neurologischen Symptome. Die Kontrollpunktion des Liquors ergab 6 Zellen/ $\mu \mathrm{l}$ bei einem Liquoreiweiß von $51 \mathrm{mg} / \mathrm{dl}$. Im Kontroll-MRT nach zwei Monaten ließen sich die MRT-Veränderungen nicht mehr nachweisen. Die Neuroborreliose kann MRT-Veränderungen verursachen, die an ein ZNS-Lymphom oder eine akute fokale oder disseminierte Encephalitis denken lassen. Die Immunphänotypisierung der Pleozytose kann zur Fehldiganose eines ZNS-Lymphoms führen.

\section{Varicella zoster-virus-Meningitis sine herpete}

W. Kunze, K.Gröger, T. Klemm, D. Beier

Muldentalkliniken, Krankenhaus Wurzen, Abteilung Kinder- und Jugendmedizin, Labor Dr.Reising-Ackermann und Partner, Landesuntersuchungsanstalt für das Gesundheits- und Veterinärwesen Sachsen, Standort Chemnitz

Hintergrund: Eine Meningitis ist im Rahmen einer Reaktivierung einer latenten Varicella-zoster-Virus (VZV)-Infektion ein seltenes Ereignis. Mit der folgenden Kasuistik möchten wir auf die Besonderheiten dieses Krankheitsbildes aufmerksam machen.

Kasuistik: Das bisher gesunde Mädchen war anamnestisch im Alter von 3 Jahren an Windpocken erkrankt. 2 Wochen vor der stationären Aufnahme wurde über Oberbauchbeschwerden wechselnder Dauer und Intensität geklagt, die mit Schulstress erklärt wurden. Mittelbar vor einer Arztvorstellung traten allgemeines Krankheitsgefühl, Übelkeit, Erbrechen und Kopfschmerzen hinzu. Fieber wurde nicht beobachtet. Die klinische Untersuchung bei stationärer Aufnahme ergab keinen Befund von Krankheitswert, die Haut war ohne Effloreszenzen, meningitische Zeichen bestanden nicht. CRP, Blutbild, Serumelektrolyte, Kreatinin, Transaminasen und Urin waren unauffällig, Immunglobuline i.S., IgGSubklassen und Komplement normal. VZV-IgG i.S. $>7800 \mathrm{mIU} / \mathrm{ml}$, VZV-IgM positiv. Ergebnis der Lumbalpunktion: Klarer Liquor in normaler Tropfenfolge. LE:592 mg/l, LZ: 3,1 mmol/l (BZ: 5,o mmol/l), Laktat: 1,68 mmo/l, Zellzahl: $958 \mathrm{Mpt} / \mathrm{l}$ (Lymph 96\%, Mono 4\%). Liquorkultur: aerob und anaerob kein Wachstum. VZV-DNA positiv. HSV-1-, HSV2und Enterovirus-PCR im Liquor negativ. Unter der Verdachtsdiagnose Herpes-simplex-Meningitis begannen wir eine Therapie mit Aciclovir und führten diese auch nach Vorliegen des virologischen Befundes über 10 Tage fort. Der weitere Verlauf war unkompliziert. Die Entlassung konnte nach 14 Tagen beschwerdefrei erfolgen.
Schlussfolgerung: Abakterielle Meningitiden können vielfältige Ursachen haben. Deshalb ist eine differenzialdiagnostische Abklärung unabdingbar. Eine der möglichen Ursachen ist die Reaktivierung des VZV mit der Ausbildung einer Meningitis. An diese Möglichkeit ist zumindest dann zu denken, wenn anamnestisch Varizellen angegeben werden. Die entscheidende diagnostische Untersuchung ist die VZV-PCR im Liquor. Serologische Untersuchungen liefern keine schlüssigen Beweise.

\section{Antikörperantwort auf FSME-Impfungen bei Kindern nach Thymekto-} mie

M. Zlamy ${ }^{(1)}$, C. Gögele ${ }^{(1)}$, R. Würzner ${ }^{(2)}$, C. Wilk ${ }^{(1)}$, R. Geiger ${ }^{(3)}$, LB Zimmerhackl (1), M. Prelog ${ }^{(1)}$

(1) Department für Pädiatrie I, Medizinische Universität Innsbruck, Austria (2) Department für Hygiene, Mikrobiologie und Sozialmedizin, Medizinische Universität Innsbruck, Austria ${ }^{(3)}$ Department für Pädiatrie III, Medizinische Universität Innsbruck, Austria

Durch die chirirgisch notwendige Thymektomie bei Herzoperationen im Kindesalter kommt es zu einer prämaturen Immunoseneszenz (Alterung des Immunsystems), gekennzeichnet durch eine Abnahme von CD4+ und CD8+ Zellen des naiven T-Zell-Pools. Ein weiteres Charakteristikum der Immunoseneszenz ist die Abnahme von spezifischen Immunantworten auf „Neoantigene“, wie Impf-Antigene.

Methoden:In einer prospektiven, kontrollierten Studie am Department für Pädiatrie wurden 44 thymektomierte Kinder ( $87 \pm 51$ Monate) und 56 nicht-thymektomierte, „altersgematchte“ (Kontrollen $82 \pm 38$ Monate) eingeschlossen. Die Frühsommer-Meningoenzephalitis-Impfung (FSME-Impfung) diente als Stimulation mit einem Neoantigen. Alle Probanden wurden mit FSME Immun Junior (Baxter, Wien) dreimalig geimpft und im Abstand von 4 Wochen die Impftiter analysiert.

Ergebnisse: Thymektomierte Kinder zeigten 2,2-fach niedriegere FSME-spezifische IgG Anitkörper als nicht-thymektomierten Kontrollen $(\mathrm{p}=0.03)$. Nach der 3 . Teilimpfung zeigten die thymektomierten Kinder vergleichbare Antikörperkonzentrationen wie die Kontrollgruppe. Die 44 thymektomierten Kinder zeigten einen signifikant erniedrigten prozentuellen Anteil an $\mathrm{CD}_{4}+\mathrm{CD}_{2} 8+\mathrm{CD}_{45} \mathrm{RA}+$ naive T Zellen im Vergleich zur Kontrollgruppe ( $55,4 \pm 12,9 \%$ versus $68,2 \pm 11,6 \%$; $p<0,0001)$. Die Zeitspanne post Thymektomie korrelierte mit der Abnahme der naiven T Zellen.

Schlussfolgerungen: Unsere Ergebnisse deuten auf eine Störung der primären Immunantwort bei thymektomierten Kindern auf FSME als neues Antigen hin, jedoch auf eine gute Gedächtnisfunktion des Immunsystems. Die Immunantwort auf Impfungen sowie neu auftretende Infektionen sollte bei thymektomierten Patienten engmaschig überwacht werden.

\section{Pränatale Parvovirus B19 Infektion als Ursache eines zerebralen Infarktes beim Neugeborenen}

S. Siebert, AM Eis-Hübinger, A.Müller, P. Bartmann, A.Heep

Universitätskinderklinik Bonn, Abteilung für Neonatologie

Einführung: Parvovirus B19 Infektionen während der Schwangerschaft können v.a. während des ersten Trimenons zu fetaler Anämie, Hydrops fetalis oder intrauterinem Fruchttod führen. Wir beschreiben eine schwere thromboembolische Komplikation bei einem Neugeborenen assoziiert mit einer pränatalen Parvovirus B19 Infektion im letzten Trimenon.

Kasuistik: Ein reifes Neugeborenes fiel postnatal durch fehlende Spontanbewegungen des rechten Armes sowie eine schmerzhafte Schwellung und livide Verfärbung am rechten Unterarm auf. Im Angio-MRT zeigte sich ein Verschluss der rechten A. subclavia, der linken A. carotis interna sowie der linken A. cerebri media. Eine Vaskulitis, eine prothrombotische Prädisposition sowie ein Herzfehler konnten als Ursache ausgeschlossen werden. Es wurde serologisch und molekularbiologisch eine im letzten Trimenon pränatal erworbene Parvovirus B19 Infektion nachgewiesen. 
Die virale DNA persistierte mehr als 4 Wochen im Serum des Patienten. Die antikoagulatorische Therapie erfolgte zunächst über 2 Wochen mit Heparin bzw. Enoxaparin i.v., dann für weitere 6 Monate mit Enoxaparin s.c. Im Verlauf normalisierte sich der Blutfluss im rechten Arm, die Hautläsion verheilte. Nach 6 Monaten zeigte sich, bei noch bestehendem sensomotorischem Defizit, eine deutliche Verbesserung der Funktionalität des rechten Armes.

Schlussfolgerung: Die Daten belegen, dass auch Parvovirus B19 Infektionen im letzten Trimenon mit schweren perinatalen Komplikationen einhergehen können und deshalb engmaschig überwacht werden müssen. Die Abklärung einer Parvovirus B19 Infektion sollte in die differenzialdiagnostischen Erwägungen bei neonatalem zerebralem Infarkt einbezogen werden.

\section{Hämatogene Osteomyelitis der Clavicula}

S. Winkler, F. Hauck, N. Bruck, J.Dinger und F. Pessler

Klinik und Poliklinik für Kinder- und Jugendmedizin, TU Dresden

Hintergrund: Weniger als 3\% der pädiatrischen Osteomyelitiden betreffen die Clavicula. Deshalb wird die Osteomyelitis der Clavicula oft verzögert diagnostiziert. Als therapeutische Maßnahmen stehen die chirurgische Wundsanierung sowie die frühzeitige parenterale antibiotische Therapie im Vordergrund.

Ziele: 1 ) Beschreibung eines Falles einer hämatogenen Osteomyelitis der Clavicula im Neugeborenenalter; 2) Analyse der internationalen Literatur von pädiatrischen Fällen hämatogener Osteomyelitis der Clavicula. Methodik: Fallbericht und Literaturanalyse.

Ergebnisse: Wir berichten über ein 3 Wochen altes Neugeborenes mit hämatogener Osteomyelitis der Clavicula. Diagnostisch richtungsweisend waren eine schmerzhafte Schwellung im Bereich der rechten Clavicula, hohes Fieber und erhöhte Entzündungswerte. Das MRT zeigte entzündliche Veränderungen der Clavicula mit einem angrenzenden Weichteilabszess. Die chirurgische Abszessdrainage sicherte die Diagnose einer Osteomyelitis. S. aureus wurde als Erreger nachgewiesen. Ein MRT zeigte 6 Wochen nach Beendigung der 4-wöchigen parenteralen Antibiose eine vollständige Befundregredienz. Weiterhin geben wir eine Zusammenfassung der veröffentlichten pädiatrischen Fälle der hämatogenen Osteomyelitis der Clavicula.

Zusammenfassung: Die hämatogene Osteomyelitis der Clavicula ist selten und wird oft verzögert diagnostiziert. Bei Fieber und schmerzhafter Schwellung im Bereich der Clavicula sollte immer an eine hämatogene Osteomyelitis der Clavicula gedacht werden.

\section{Kawasaki-Syndrom unter dem Bild einer bakteriell-septischen Hepatitis}

Anders, E., M. Wegner, A. Findeisen, J.-P. Haas und R. Bruns

Ernst Moritz Arndt-Universität Greifswald, Zentrum für Kinder- und Jugendmedizin, Klinik und Poliklinik für Kinder- und Jugendmedizin

Einleitung: Das Kawasaki- oder mukokutane Lymphknoten-Syndrom ist eine febrile, exanthematische, multisystemische Vasculitis, deren Ätiologie bisher nicht bekannt ist und für die es keinen spezifischen diagnostischen Labortest gibt. Es werden deshalb auch heute noch klinische Haupt- und Nebensymptome als diagnostische Leitschiene benutzt; die Vielfalt der möglichen Organmanifestationen kann aber in der Praxis manchmal zu erheblichen Schwierigkeiten führen.

Kasuistik: Ein 8-jähriger Knabe (mit Scharlach inkubiert) wird mit V.a. Hepatitis (dunkler Urin, entfärbte Stühle) eingewiesen. 2 Tage vor Aufnahme feinfleckiges Exanthem und Halsschmerzenl; kein Fieber. Im Verlauf von 12 Stunden kam es zum Fieberanstieg, zur Tachycardie und Tachypnoel; es persistierte das Exanthem, Skleren- und Hautikterus waren zunehmend. Gleichzeitig bestanden Fuß- und Handrückenödeme, ein symmetrisches Palmarerythem, generalisierte Lymphknotenschwellungen, Tonsillitis ohne Beläge, Erdbeerzunge, rissige Lippen und Vigilanzschwankungen. Labordiagnostik: Transaminasenanstieg (10-fach), ges. Bilirubinerhöhung (8-fachl; davon direktes Bilirubin 98 ।; indirektes Bilirubin 31,5), CrP auf $115 \mathrm{mg} / \mathrm{l}$ erhöht, im Verlauf Anstieg des $\mathrm{CrP}$ auf 226mg/l, Proteinurie $1198 \mathrm{mg} / \mathrm{d}$, Immunglobuline einschl. IgE normal. Röntgen-Thorax - interstitielle Pneumonie und dezente Pleuraeffusionen (Pleuritis). Abdominelle Sonografie - lediglich Störung des Gallenabflusses, kein Gallenblasen-Hydrops. EKG und Echokardiografie - mehrfach kein pathologischer Befund. Die mikrobiologischen Untersuchungen konnten eine Reihe gesuchter viraler, bakterieller und parasitärer Infektionskrankheiten nicht bestätigen. CephalosporinTherapie bei Scharlachinkubation und der Zusatz von Gentamycin bei Begleitpleuritis waren ohne klinischen Erfolg. Das Nichtansprechen auf die antibiotische und antipyretische Therapie länger als 5 Tage und die beschriebenen klinischen Symptome mit kontinuierlicher Verschlechterung des Allgemeinzustandes führten zur Arbeits-Diagnose KawasakiSyndrom und damit zur kombinierten Immunglobulin-ASS-Therapie; darunter langsame klinische Besserung mit allmählichem Rückgang des Ikterus und Verschwinden aller beschriebenen Symptome sowie Normalisierung aller pathologischen Laborbefunde.

Zusammenfassung: Die epidemiologischen Daten und klinischen Symptome lassen zwar eine infektiöse Ursache des Kawasaki-Syndroms vermuten. Die bisher ungeklärte Ätiologie und die Vielfalt der klinischen Symptome dieser Erkrankung bereiten aber mangels eines diagnose-spezifischen Labortests häufig diagnostische Schwierigkeiten. So müssen wir auch heute noch akzeptieren, dass die Arbeitsdiagnose Kawasaki-Syndrom in der Regel sowohl aus der Synopsis der bunten Vielfalt klinischer Zeichen und Symptome als auch aus der Therapieresistenz der initialen Antibiotikatherapie resultiert. Auch bei unserem Patienten führte die vordergründig bestehende Hepatitis bei Scharlachinkubation erst sekundär zur Diagnose. Die anfänglich breit gefächerte Labordiagnostik wird man wohl aus Gründen der ärztlichen Sorgfalt akzeptieren müssen, solange es den spezifischen und zur Diagnose führenden Labortest nicht gibt. Wie kann eine effiziente und kostensparende Diagnostik aussehen?

\section{Schwere Komplikationen bei hospitalisierten Kindern mit akuter Gastroenteritis (AGE) durch Rotavirus (RV) oder andere Erreger - eine retrospektive Studie}

Kaiser, $\mathrm{P}^{(1)}$; Borte, $\mathrm{M}^{(2)}$; Kliemann, G ${ }^{(3)}$; Zimmer, KP ${ }^{(3)}$; Huppertz, H.I. ${ }^{(1)}$

1) Prof.-Hess-Kinderklinik, Klinikum Bremen-Mitte $\mathrm{gGmbH}{ }^{2}$ ) Kinderklinik St Georg, Leipzig ${ }^{3}$ ) Universitätskinderklinik Giessen

Einleitung: Jedes Kind erkrankt an einer RV-AGE, v.a in den ersten Lebensjahren|; die Hospitalisierungsrate ist hoch, die Mortalität in Ländern mit schlechter Gesundheitsinfrastruktur ist hoch. In Deutschland gilt die Erkrankung als harmlos, Daten zu spezifischen Komplikationen existieren aber nicht.

Methoden: Die Akten aller über mind. eine Nacht hospitalisierten Kinder $\leq 6$ Jahre von 10/2002 - 5/2008 mit den ICD-10 Codes für infektiöse Enteritis (Aoo-Aog) an 3 grossen Kinderkliniken wurden retrospektiv nach einem definierten Protokoll analysiert.

Ergebnisse: 7234 Fälle wurden eingeschlossen; das Alter betrug 1 Jahr im Median, die mittlere Krankenhausverweildauer betrug 6,6 Tage. $20,8 \%$ aller Kinder hatten chronische Grunderkrankungen Bei 2181/7234 (30,1\%) wurden RV nachgewiesen. 6/7234 Kinder starben, 5 mit AGE, ein Frühgeborenes an einer NEC im Kontext einer RV Infektion. In 45,5\% der RV-Fälle vs $61,1 \%$ AGE lagen andere akute Diagnosen vor $(\mathrm{p}<0,01)$; neurologische, kardiale und abdominelle Probleme waren häufiger in der AGE-Gruppe, in der RV-GE Gruppe fanden sich etwas mehr metabolische Probleme, ansonsten keine wesentlichen Unterschiede. In 79 Fällen fand sich eine hypertone Dehydration ( $\mathrm{Na}>150 \mathrm{mmol} / \mathrm{l}), 50$ $(63,3 \%)$ davon waren RV positiv, in 14 (17,7\%) Fällen war nicht nach RV gesucht worden, in 19\% wurde RV ausgeschlossen. In 21 Fällen fand sich eine schwere hypertone Dehydration ( $\mathrm{Na}>160 \mathrm{mmol} / \mathrm{l})$, davon $15 \mathrm{RV}$ positiv (alle $\mathrm{p}<\mathrm{O}, 01$ ).

Schlussfolgerung: Die hypertone Dehydratation ist offensichtlich eine seltene, aber typische Komplikation der RV-AGE. Eine mögliche ZNSSchädigung ist zu beachten. 


\section{Clostridium difficile Ribotyp 027 Nachweis im Saarland}

K.Speck, I.Joost, M.Herrmann, L. v.Müller

Institut für Medizinische Mikrobiologie und Hygiene, Universitätsklinikum des Saarlandes

Clostridium difficile ist die häufigste Ursache für Antibiotika assoziierte Durchfallerkrankungen („C. difficile associated diarhoea“, CDAD). In den vergangenen Jahren konnte sich von USA und Canada ausgehend ein neuer epidemischer C. difficile Stamm mit besonders hoher Pathogenität auch in Europa ausbreiten, bevorzugt in England, Frankreich und den Benelux Ländern. Seit 2007 wurden auch vereinzelte Ausbrüche in Deutschland beschrieben. Epidemische Ribotyp 027 Stämme (Toxinotyp V) sind charakterisiert durch eine breite Antibiotikaresistenz und eine verstärkte Toxinproduktion aufgrund von Mutationen im Toxin Repressor Gen tcdC (18bp Deletion). Daten zur Prävalenz der verschiedenen C. difficile Stämme in Deutschland sind bislang nicht verfügbar. Zum Teil liegt das Fehlen epidemiologischer Daten an der Komplexität der Typisierungsmethoden, die i.d.R. nur in Referenzlaboratorien etabliert sind (z.B. PCR Ribotypisierung, PFGE). Diese DNA-Banden basierten Methoden sind mäßig standardisierbar und erlauben nur bedingt die Vergleichbarkeit von Ergebnissen zwischen verschiedenen Laboratorien. Eine gute Reproduzierbarkeit und Vergleichbarkeit von Typisierungsergebnissen ist mithilfe sequenzbasierter Methoden möglich. „Single locus" basierte Genotypisierungsmethoden bestechen durch Einfachheit der Handhabung und Interpretation. Die Sequenzierung des surface layer protein A (slpA) Gens ermöglicht die Genotypisierung epidemisch relevanter C. difficile Stämme. In dieser prospektiven Untersuchung wurden C. difficile Isolate aus verschiedenen Kliniken des Saarlandes mit slpA Sequenzierung typisiert (slpAST). Eine zusätzliche Charakterisierung erfolgte durch Bestimmung der Empfindlichkeit gegen Makrolide (Clarithromycin) und Chinolone (Moxifloxacin) sowie durch Genotypisierung des Toxin Repressor Gens tcdC. Es konnten gehäuft Ribotyp 027 Infektionen im Saarland nachgewiesen werden (50\%)।; dies kann als sicheres Indiz für die weitere Ausbreitung des 027 Epidemiestamms gewertet werden. Ribotyp oo1 (25\%) wurde als zweiter HochprävalenzStamm mit Multiresistenz gegen Makrolide und Chinolone identifiziert. Sporadisch auftretende C. difficile Genotypen waren dagegen i.d.R. empfindlich die getesteten Antibiotika. slpAST ist eine vielversprechende Methode zur Typisierung klinisch-relevanter C. difficile Stämme, die sich aufgrund ihrer guten Reproduzierbarkeit und Standardisierung für epidemiologische laborübergreifende Studien anbietet.

\section{Vergleich der Ergebnisse eines Gruppe A Streptokokken Schnelltests durchgeführt von Laborpersonal bzw. ärztlichem Personal - Konse- quenzen für die klinische Praxis}

M. Hufnagel, K.Brell, S.Fukala, U.Schmidt, P.Henneke, R.Berner Zentrum für Kinder- und Jugendmedizin, Sektion Pädiatrische Infektiologie, Immunologie und Vakzinologie, Universitätsklinikum Freiburg

Hintergrund: Gruppe A Streptokokken sind häufige Erreger von Tonsillopharyngitiden. Um unnötige Antibiotikatherapien zu vermeiden, ist ein Erregernachweis zu fordern. Zur Diagnostik sind der kulturelle Nachweis und Antigenschnellteste geeignet. Schnellteste haben den Vorteil einer Diagnose innerhalb weniger Minuten. Am ZKJ Freiburg kommt seit Jahren ein gut etablierter Schnelltest neben der Kultur zum Einsatz. Die Tests werden sowohl routinemäßig von Laborpersonal (LP) als auch im Bereitschaftsdienst von ärztlichem Personal (̈̈P) durchgeführt. Die Ergebnisse beider Testverfahren - durchgeführt von LP bzw. ÄP - wurden miteinander verglichen.

Methodik: Retrospektive Analyse der Ergebnisse eines Schnelltests vs. Kultur aus dem Jahr 2008 mit Vergleich von Sensitivität, Spezifität, positivem und negativem Vorhersagewert bei Durchführung der Tests durch LP oder ÄP.

Ergebnisse: Im Jahr 2008 wurden am ZKJ Freiburg 369 parallele Bestimmungen von Schnelltest und Kultur durchgeführt. Auswertbar waren 360 Testpaare. 339 Testungen wurden von LP und 21 von ÄP durchge- führt. 20,6\% aller Tests waren kultur-positiv (74/360). Die Sensitivität des Schnelltests betrug 55,4\% (41/74), sie war in Händen von LP höher $(56,9$ vs. $44,4 \%)$. Spezifität, positiver und negativer Vorhersagewerte waren deutlich niedriger, wenn die Tests von ÄP durchgeführt wurde (8,3 vs. 98,2\% für Spezifität; 26,7 vs. 88,1\% für PVW; 16,7 vs. 90,6\% für NVW). Schlussfolgerungen: Die Sensitivität des verwendeten Schnelltests war niedriger als in der Literatur angegeben. Die Testperformance war deutlich schlechter, wenn Tests durch ÄP durchgeführt wurden. Eine Delegation an nicht geschultes Personal ohne spezielles Training ist nicht sinnvoll. Stichprobenartige Qualitätskontrollen gegenüber dem Goldstandard Kultur sind notwendig.

\section{Nosokomiale Infektionen bei pädiatrischen Intensivpatienten nach kardiochirurgischen Operationen}

T.Dresbach, J. Gillen, A. Müller, J. Breuer, A.Simon

Pädiatrische Infektiologie, Zentrum für Kinderheilkunde am Universitätsklinikum Bonn

Neonatologische und pädiatrische Patienten mit angeborenen Herzfehlern haben nach kardiochirurgischen Operationen ein erhöhtes Risiko für nosokomiale Infektionen (NI), insbesondere für postoperative Wundinfektionen und Katheter-assoziierte Blutstrominfektionen. Ausgehend von einer systematischen Analyse der international publizierten Studien sollen folgende Fragen beantwortet werden: Welche Infektionsraten pro 100 Operationen und welche Inzidenzdichten der NI pro 1000 Patiententage bzw. pro 1000 Katheter-Anwendungstage wurden beobachtet? Welche NI kommen vor allem vor? Was sind die wichtigsten Erreger und welche Rolle spielt die perioperative Antibiotikaprophylaxe? Gibt es Risikofaktoren für NI, die in multivariaten Analysen gesichert wurden? Welche Rolle spielen kontagiöse Virusinfektionen der Atemwege (Respiratory Syncytial Virus u.a.), virale Gastroenteritiden (Rotavirus, Norovirus) und multiresistente bakterielle Infektionserreger (MRSA, ESBL-Bildner) in diesem Kontext? Was können wir für die Praxis aus Studien lernen, die durch gezielte Interventionen eine Abnahme der Inzidenzdichte von NI bei pädiatrischen Patienten nach Herzoperationen erreicht haben? Welchen Nutzen hat eine Fortführung der NI-Surveillance über den Tag der Entlassung hinaus?

\section{HSV-1 Viremia as Cause of Febrile Neutropenia in an Immunocompro- mised Child}

D. Holzinger, J.Kühn, K.Ehlert and AH. Groll

Department of Pediatric Hematology and Oncology, Institute of Immunology and Department of Medical Microbiology, University Hospital Münster, Münster, Germany

Background: The standard of care in neutropenic patients with fever of unknown origin includes the initiation of empirical antibacterial and antifungal therapy. However, many patients do not respond and need further diagnostic work up that may eventually lead to the identification of a potentially life-threatening, but treatable condition.

Case report: The patient was a 4-year-old Caucasian boy with very severe aplastic anaemia (VSAA) who had received several courses of glucocorticosteroids for suspected immune thrombocytopenia at the referring institution prior to diagnosis. He was started on immunosuppressive therapy (IST) consisting of anti-thymocyte globuline, prednisone, and cyclosporine A complemented by voriconazole and trimethoprim/sulfamethoxazole prophylaxis. Five days after the start of IST, the patient presented with a new fever of up to $39.0^{\circ} \mathrm{C}$, an absolute neutrophil count of $\% 3 \mathrm{C}_{500} / \mu \mathrm{l}$ and a C-reactive protein (CRP) of $1.9 \mathrm{mg} / \mathrm{dl}$ (normal: \%3Co.5 $\mathrm{mg} / \mathrm{dl}$ ). Vital signs were within normal limits, and physical examination was negative for an infectious focus. After blood cultures, the patient was started on empirical ceftazidime plus gentamycin. The patient defeveresced within 48 hours and stayed in good clinical condition. The CRP level had dropped from a maximum of $9.5 \mathrm{mg} / \mathrm{dl}$ on day 6 to $8.9 \mathrm{mg} / \mathrm{dl}$ on day 7 . On day 8 , the patient developed low grade temperatures of up 
to $38.2^{\circ} \mathrm{C}$. Physical examination now revealed three small oral aphthous ulcers but no other infectious foci. After repeat blood cultures and oral swab and blood specimens for detection of herpes viruses, the patient's antibacterial regimen was escalated to meropenem and teicoplanin and empirical therapy with liposomal amphotericin B and intravenous acyclovir was started. During the ensuing five days, the patient had recurrent fevers of up to $39.2^{\circ} \mathrm{C}$, and the CRP rose to a maximum of $24.8 \mathrm{mg} / \mathrm{dl}$. All blood cultures remained negative, and serial serum galactomannan ELISA and a high-resolution computed tomography of the chest were within normal limits. However, the PCR result for the oral swab specimen returned positive for herpes simplex virus type 1 (HSV-1) viral DNA, and HSV-1 viral DNA was detected in blood by PCR as well, presumably representing viral reactivation because of a positive HSV-1 IgG-titer on admission. With continuing empiric antibacterial, antifungal and specific antiviral therapy, the patient's temperature had returned to normal by day 13 with subsequently decreasing CRP values. Follow-up HSV-1 PCR testing in serum on day 17 was negative.

Conclusions: This case report illustrates that screening for HSV in Immunocompromised neutropenic patients with fever of unknown origin that does not respond to empirical antibacterial and antifungal therapy may discover HSV reactivation that can be treated successfully before the development of potentially life-threatening organ manifestations.

\section{Fatal cardiac failure due to fulminant influenza B virus myocarditis in a 5 year old previously healthy girl}

H. Frank, W. Kiess, C.Wittekind, T. Gradistanac, U. Liebert, M. Schulz, A.Koerner, W. Siekmeyer, V. Schuster Hospital for Children and Adolescents, University of Leipzig and Leipzig Institute of Pathology and Virology

Acute myocarditis is characterised by the rapid development of life-threatening congestive heart failure and arrhythmias. The intial stages of this disorder apparently result from direct cytopathic effects on the ventricular and atrial myocardium. Later stages of progressive decompensation may result from immune-mediated myocyte destruction. So far many steps of this immunologic cascade have been unknown. We report here on the case of a previously healthy 5 year old girl who developed a fulminant myocarditis due to acute infection with influenza virus type $B$. Her past clinical history was uneventful except for a HHV6-infection years ago and frequent infections of the upper airways. Therefore she undervent an adenotomy one year before. The vaccination was completely done in reference to the age of the patient. A vaccination against influenza has not occurred. One week before admission, the girl presented with a mild infection with rhinitis cough and fever. Initially one started with an symptomatic therapy, later on she got antibiotics (cefpodoxim). When she went to our hospital, the patient was in a bad shape. On physical examination the skin was pale, the mucous membrane of the mouth was dry, the throat was red, the lips were zyanotic, the lung was inconspicious. The girl had abdominal pain. At the cardial examination, there was neither a systolic murmur, nor an arrhythmia audible, the oxygenation of the blood was normal. But the blood pressure was low with $75 \mathrm{mmHg}$ (systolic pressure). Within 12 hours, the girl was transferred to our intensive care unit. The symptomatic therapy was extended and the patient additional got aciclovir iv (DD herpesencephalopathy). Despite of all the taken measures the Cardiac arrest occurred suddenly, resuscitation efforts were not successful, and the patient died of congestive heart failure 48 hours after admission to the hospital. Lymphocytic infiltration of cardiac tissues and virologic studies confirmed the suspected diagnosis of acute viral myocarditis. In conclusion, influenza virus type B is one of the infective agents that can cause rapid and fatal myocarditis in previously perfectly healthy children. Early cardiac support may be the only option to prevent from fatal outcome.
HIV/AIDS und Suizid bei Adoleszenten und jungen Erwachsenen im Zeitalter der HAART

H.Zillhardt, T.Dresbach, J.Gillen, A. Müller, A.Simon

Pädiatrische Infektiologie, Zentrum für Kinderheilkunde am Universitätsklinikum Bonn

Hintergrund: Die Einführung der hochaktiven antiretroviralen Therapie (HAART) im Jahr 1996 hat die Mortalität und Morbidität HIV positiver Menschen signifikant gesenkt. Unter Menschen mit HIV/AIDS ist die Suizidrate signifikant erhöht. Die Zeit bis zu einem Jahr nach der Ergebnismitteilung ist mit dem höchsten Suizidrisiko verbunden, Die hier vorgestellte Untersuchung (zwei unabhängigen Studien: im Kollektiv der Menschen mit AIDS in den USA zwischen 1991 und 2001 sowie im Kollektiv der Menschen mit einem HIV positiven Status in England und Wales in den Jahren 1997-2001) geht der Frage nach, wie sich Einführung der HAART auf die Suizidrate ausgewirkt hat.

Methodik: Für die USA wurden die Daten der Mortality Multiple Cause-of-Death Public-use Records 1991-2001 des National Center for Health Statistics sowie der Datenbank AIDS Public Information Data Set 1981-2002 des Center for Disease Control und des Population Estimates des U.S. Census Bureau ausgewertet. In England und Wales standen die Daten aus dem Survey of prevalent HIV infections diagnosed sowie der HIV Mortality Data Bank des Communicable Disease Surveillance Centre und andererseits aus der Mortality Statistics and Population Estimates des Office for National Statistics in London zur Verfügung.

Ergebnisse: In der vorliegenden Arbeit wurde mittels diachronen Vergleichs [Prä-HAART-Ära (1991-1995) vs. HAART-Ära (1997-2001)] erstmals festgestellt, dass nach Einführung der antiretroviralen Therapie die suizidspezifische standardisierte Mortalitätsrate (SMR) der 15-24 jährigen männlichen Adoleszenten in den USA um 70\% (von 2.67 auf 4.54) seit Einführung der HAART anstieg, während der allgemeine Trend bei allen übrigen Altersgruppen (25-34; 35-44; 45-54; 55-64 Jahre) um 50\% rückläufig war. Gegenüber dem alters- und geschlechtsentsprechenden Kollektiv der Allgemeinbevölkerung sind die Suizidraten der HIV-positiven Adoleszenten in England und Wales um das 105fache erhöht.

Diskussion: Seit Einführung der HAART wurde bei 15-24 Jährigen jungen Männer mit AIDS ein Anstieg des Suizidrisikos um 70\% dokumentiert. Gerade in dieser Altersgruppe sind verstärkte Präventions- und Interventionsanstrengungen erforderlich.

\section{Adenovirusinfektionen - Vortäuschung bakterieller Superinfektion W. Kunze, D. Beier, K.Gröger \\ Muldentalkliniken, Krankenhaus Wurzen,Abteilung Kinder- und Jugend- medizin, Landesuntersuchungsanstalt für das Gesundheits- und Veterinär- wesen Sachsen, Standort Chemnitz}

Hintergrund: Respiratorische Adenovirus (ADV)-Infektionen werden wegen erhöhter akute Phase Parameter häufig als bakteriell verursacht gedeutet. Ziel der Untersuchung war die Bestimmung von Entzündungsindikatoren (CRP, Leukozyten- und Neutrophilenzahl im peripheren Blut, IL-6) bei Kindern mit respiratorischen ADV - Infektionen und der Vergleich mit den Ergebnissen bei Patienten mit Influenzavirus- und anderen viralen respiratorischen Infektionen.

Patienten und Methode: Die Untersuchung umfasste 188 Patienten: 106 ADV positive, 32 ADV negative, 17 Doppelinfektionen (12 mal ADV/ RSV, 5 mal ADV/Influenza) sowie 33 Patienten mit Influenzavirusinfektion im Alter von 1 Monat bis 151/2 Jahre. Der ADV-Nachweis erfolgte mittels Nasopharyngealabstrich und quantitativer Bestimmung von humaner ADV-DNA mittels real-time PCR.

Ergebnisse: Patienten mit ADV-Infektionen zeigten im Vergleich zu ADV-negativen sowie Influenzavirus-positiven Patienten signifikant erhöhte CRP-, Leukozyten- und (absolute) Neutrophilen-Werte. Bei 41,5\% der ADV-positiven Patienten wurden CRP-Werte $>50 \mathrm{mg} / \mathrm{l}$, bei $8(81,8 \%)$ von 11 Patienten Werte $>100 \mathrm{mg} / \mathrm{l}$ und bei $4(100 \%)$ von 4 Patienten Werte $>$ 20omg/l gemessen. Bei IL-6 bestand auch Signifikanz zwischen ADVpositiven und ADV-negativen Patienten (33,15 vs. 22,0 ng/l, $\mathrm{p}=0,035)$. 
Eine Antibiotikatherapie hatte keinen Einfluss auf das Krankheitsbild einer ADV-infektion.

Diskussion: Das CRP gilt als Kriterium zur Differenzierung viraler von bakteriellen Infektionen. Aufgrund neuerer Untersuchungen kann dies nicht mehr unwidersprochen bleiben. Weder anamnestische, klinische noch die Kombination von CRP und (absoluter) Leukozytenzahl sind für die Differenzierung von ADV- und bakterieller Infektion geeignet. Wenige Studien belegen die Tatsache, dass CRP-, Leukozytenwerte sowie IL- 6 bei ADV- im Vergleich zu anderen viralen Infektionen signifikant erhöht sind.

Schlussfolgerung: ADV-Infektionen können bakterielle Infektionen imitieren. In Zukunft sind weitere Studien erforderlich, die im Ergebnis eine Differenzierung ADV-verursachter von bakteriellen Infektionen ermöglichen.

\section{Persistiernde HHV-6 Infektion nach Leber-Transplantation - erfolgrei- che Therapie mit der 2,5fachen Dosis von Cidofovir \\ C. Dohna-Schwake ${ }^{(1)}$, M.Fiedler ${ }^{(2)}$, N.Gierenz ${ }^{(1)}$, A.Ballauf ${ }^{(1)}$, A. Breddemann (3), S. Läer ${ }^{(3)}$, P. Hoyer ${ }^{(1)}$ \\ 'Zentrum für Kinder- und Jugendmedizin, Universität Duisburg-Essen \\ Institut für Virologie, Universität Duisburg-Essen \\ ${ }^{3}$ Klinische Pharmazie, Universität Düsseldorf}

Fallbericht: Ein 1,5 Jahre altes Mädchen wurde aufgrund eines chronischen Cholestase-Syndroms lebertransplantiert. Am Morgen der Transplantation hatte das Mädchen eine Körper-Temperatur von $38,1^{\circ} \mathrm{C}$. Nach der ersten komplikationslosen Woche kam es zu einem Anstieg der Transaminasen. Unter dem klinischen und histologischen Bild einer Abstoßung wurde die Patientin mit einem Prednison-Stoß therapiert. Hierunter zeigte sich keine Besserung, es kam im Verlauf zusätzlich zu rezidivierenden Fieberschüben, respiratorischem Versagen mit Langzeitbeatmung und einem feinfleckigen, $z$. T. flammend rotem makulopapulösem Exanthem. In der Leber-Biopsie, im Pleura-Punktat und im Blut konnte HHV-6 DNA nachgewiesen werden. Es wurde eine Therapie mit der Standard-Dosierung von $5 \mathrm{mg} / \mathrm{kg} /$ Woche Cidofovir begonnen, was zu keiner klinischen Besserung führte. Im Rahmen einer CidofovirPharmakokinetik Studie des Instituts für Klinische Pharmazie Düsseldorf wurde eine erhöhte Cidofovir-Clearance gemessen und daraufhin die Dosis auf 12,5 mg/kg/Woche erhöht. Bereits in der ersten Woche nach Gabe kam es zum Verschwinden des Exanthems, im weiteren Verlauf zur Normalisierung der Leberwerte und der respiratorischen Situation. Nach 100 Tagen Aufenthalt auf der Intensivstation konnte die Patientin in gutem $\mathrm{AZ}$ verlegt werden.

Schlussfolgerung: Dieser Fallbericht zeigt die Effektivität und Toleranz einer erhöhten Cidofovir-Dosis bei persistierender HHV-6-Infektion und beweist die Notwendigkeit von Medikamentenstudien im Kindesalter.

\section{Oseltamivirtherapie der Influenza im Säuglingsalter \\ K Siedler und H Skopnik \\ Klinikum Worms}

Hintergrund: Bei den jährlich wiederkehrenden saisonalen Influenzaepidemien während der Wintermonate erkranken bis zu 30\% aller Kinder. Kleinkinder und insbesondere Säuglinge haben ein erhöhtes Morbiditäts-, Komplikations- und Mortalitätsrisiko. Kinder $<1$ Jahr weisen ebenso hohe Hospitalisierungsraten auf wie erwachsene Hochrisikopatienten. Die Effektivität und Sicherheit von Oseltamivir bei Kindern im Alter von 1-12 Jahren ist gut belegt. Für Säuglinge ist die Therapie derzeit nicht zugelassen. Ziel war es, Effektivität und Verträglichkeit der Oseltamivirtherapie im Säuglingsalter zu evaluieren.

Methoden: Während der Influenzasaisons 2003-2007 wurden insgesamt 157 Kinder $<1$ Jahr mit durch den Influenza A/B Rapid Test ${ }^{\circledR}$ nachgewiesener Influenza stationär aufgenommen und mit Oseltamivir behandelt. Demographische Daten, Vorerkrankungen, Symptome und Befunde der klinischen Untersuchung, Ergebnisse der Labordiagnostik, Röntgenbefunde, angewandte therapeutische Maßnahmen sowie der klinische Verlauf wurden retrospektiv analysiert. Ergebnisse: Das mittlere Alter war 6,3 $\pm 3,3$ Monate. Insgesamt 15 (9\%) Kinder hatten bestehende Vorerkrankungen, darunter kardiovaskuläre $(n=6)$, pulmonale $(n=7)$ und dermatologische $(n=2)$. Die ersten Symptome traten weniger als $48 \mathrm{~h}$ vor Aufnahme auf. Die häufigsten Symptome abgesehen von Fieber $\left(38,8 \pm 0,9^{\circ} \mathrm{C}\right)$ waren Rhinitis $(n=134)$, Pharyngitis $(n=132)$, Husten $(\mathrm{n}=114)$, Ernährungsschwierigkeiten $(\mathrm{n}=73)$, Otitis $(\mathrm{n}=39)$, Konjunktivitis $(n=29)$ und Erbrechen $(n=25) .7$ Kinder hatten einen Fieberkrampf. Laborergebnisse: CRP $12 \pm 16 \mathrm{mg} / \mathrm{l}$ und Leukozytenzahl $10.200 \pm 5800 / \mu \mathrm{l}$. 2 Kinder präsentierten sich initial mit CRP-Werten \%3 ${ }_{5} 50 \mathrm{mg} / \mathrm{l}$, als Zeichen einer begleitenden bakteriellen Infektion. Eine Oseltamivirtherapie mit 2x2mg/kg KG wurde nach Aufklärung und Einverständnis der Eltern begonnen. Der komplette Therapiezyklus (5d) wurde von allen bis auf ein Kind durchlaufen. 128/157 Säuglingen entfieberten in weniger als 36 Stunden beziehungsweise $136 / 157$ in weniger als 48 Stunden nach Therapiebeginn. Unter Therapie traten Erbrechen $(n=62)$, Diarrhoe $(n=34)$ und Ernährungsschwierigkeiten $(n=6)$, Exanthem $(n=4)$, Unruhe $(n=6)$ und Berührungsempfindlichkeit $(\mathrm{n}=2)$ neu auf. 13 Kinder (8\%) wurden wegen Sekundärinfektionen antibiotisch behandelt, darunter Pneumonie $(n=6)$, Otitis $(n=2)$, Meningokokkenmeningitis, HWI, Sepsisverdacht, Streptokokkenangina und Panaritium (jeweils $n=1$ ).

Schlussfolgerungen: Die Erfahrungen mit Oseltamivir bei Säuglingen sind mit jenen bei älteren Kindern vergleichbar, insbesondere ist die Komplikationsrate durch bakterielle Sekundärinfektionen unter Therapie niedrig. Eine Zulassung für diese Altersgruppe ist aufgrund ihrer besonderen Gefährdung wünschenswert.

X-lymphoproliferatives Syndrom (XLP)-ähnliche Erkrankung bei einem 16-jährigen Mädchen nach primärer EBV-Infektion

F. Hauck ${ }^{(1)}$, S. Ehl ${ }^{(2)}$, J. Roesler ${ }^{(1)}$, M. Suttorp ${ }^{(3)}$

${ }^{1}$ Immunologische Ambulanz und ${ }^{3}$ Abteilung Hämatologie/Onkologie, Klinik und Poliklinik für Kinder- und Jugendmedizin, Universitätsklinikum CG Carus Dresden

${ }^{2}$ Immundefektzentrum Freiburg Kinder und Jugendliche, Universitätsklinikum Freiburg

Fragestellung: Die EBV-Infektion (EBV-I) des immunkompetenten Individuums verläuft klinisch inapparent oder unter dem Bild der infektiösen Mononukleose (IM), einer sich selbstlimitierenden lymphoproliferativen Erkrankung. Bei primär oder sekundär immuninkompetenten Individuen trägt sie oder ihre Reaktivierung zur Virus-assoziierten hämophagozytischen Lymphohistiozytose (VA-HLH), zur post-transplantationellen lymphoproliferativen Erkrankung (PTLD) und zur Entstehung maligner Lymphome bei. Über die immunbiologischen Vorgänge ist wenig bekannt.

Material und Methode: Onkologischer Fallbericht mit immunologischer Diagnostik.

Ergebnisse: Bei leerer Eigen- und Familienanamnese entwickelte die 16jährige Patientin im Rahmen einer EBV-I eine fulminante IM und eine VA-HLH, die nach dem Protokoll HLH-2004 behandelt wurde. Nach initialem Therapieansprechen kam es neben zahlreichen schweren Komplikationen zum Progress mit Anstieg der EBV-Last und der Etablierung von tertiärem lymphatischen Gewebe in Leber, Milz, Lunge, Larynx, Skelettsystem und Haut. Da histologischen und molekularbiologische ein malignes Lymphom nicht auszuschließen war, wurde die Therapie nach dem Protokoll B-NHL-BFM o4 fortgesetzt. Die inzwischen kachektische Patientin entwickelte multiple Organnekrosen und einen multifokalen zentralnervösen Befall, so dass unter der Annahme einer PTLDähnlichen Situation die Therapie nach dem Protokolls PED-PTLD-Pilot 2004 fortgesetzt wurde. Es kam zur Reduktion der EBV-Last unter die Nachweisgrenze, zu Defektheilungen im Bereich aller lymphoproliferativen Infiltrate und zu schweren Osteonekosen. Die immunologische Basisdiagnostik und insbesondere die Degranulation und Zytotoxizität der natürlichen Killerzellen (NK) und zytotoxischen T Lymphozyten 
(CTL) sowie die Anzahl der natürlichen Killer-T-Zellen (NKT)waren unauffällig.

Diskussion: Dieser schwere Verlauf der EBV-I ist vergleichbar mit der für den primären Immundefekt X-lymphoproliferatives Syndrom (XLP) beschriebenen Situation. Die XLP wird in zwei Formen, XLP-1 und XLP2, unterteilt. Für die XLP-1 ursächlich sind Mutationen im Adaptermolekul signalling lympocytic activation molecule (SLAM) associated protein (SAP), die neben einer reduzierten Zytotoxizität der NK und CTL zu einem intrathymischen Entwicklungsstopp der NKT führen. Der XLP-2 liegen Mutationen im antiapoptotischen Protein X-linked inhibitor of apoptosis (XIAP) zugrunde, die wahrscheinlich zu einer gestörten peripheren NKT-Homöostase führen. Beiden XLP-Varianten zentral ist also ein X-chromosomal rezessiver NKT-Zelldefekt. Vereinzelt finden sich klinisch vergleichbare Fälle, teilweise mit reduzierter NKT-Zellzahl und wahrscheinlich autosomal rezessivem Erbgang ohne bisher möglicher molekularbiologischer Zuordnung.

Schlussfolgerung: Die hier zu vermutenden immunologisch Pathophysiologie bleibt unklar. Es bedarf weitere immunologischer Forschung zum besseren Verständnis der NKT-Funktion insbesondere im Kontext der Herpesvirusinfektionen.

\section{Unterscheidung frischer von vergangenen Masern-Infektionen durch die Bestimmung der Avidität des spezifischen IgG im Serum K.Steinhagen ${ }^{(1)}$, M. Prahl (1) P. Schäfer ${ }^{(2)}$, KP Wandinger ${ }^{(1)}$, S.Saschenbrecker ${ }^{(1)}$, W.Schlumberger ${ }^{(1)}$, W. Stöcker ${ }^{(1)}$ \\ ${ }^{1}$ Institut für experimentelle Immunologie der EUROIMMUN AG, Lübeck \\ ${ }^{2}$ Medizinisches Versorgungszentrum (MVZ), Ludwigsburg}

Einleitung: Bei klinischem Verdacht auf Masern stellt sich häufig die Frage, ob ein positives Masern-IgG im Serum von einer frischen oder vergangenen Infektion herrührt. IgM-Antikörper gelten als Indikatoren des Krankheitsbeginns, sie sind jedoch nur vorübergehend und nicht bei allen Patienten nachweisbar, und in Fällen von IgM-Persistenz, Reaktivierung oder polyklonaler Stimulierung (beispielsweise bei einer EBVInfektion) wird man in die Irre geführt. Deshalb gehört es heute zum Stand der Technik, die Avidität des Masern-spezifischen IgG zu bestimmen: Niedrig-avide Antikörper weisen auf eine frische Infektion hin, hoch-avide Antikörper kennzeichnen die abgelaufene Infektionen. Methoden: Untersucht wurden Seren von 11 Patienten (aus Gebieten aktueller Masernausbrüche) mit Verdacht auf eine frische Masern-Infektion, 7 Patienten mit subakuter sklerosierender Panenzephalits (SSPE), 14 Patienten mit akuter EBV-Infektion und von 29 Blutspendern mit positiver Masern-Anamnese, sowie Seren von 70 Probanden mit unterschiedlich lange zurückliegender Masern-Impfung. Sowohl das Masernspezifische IgM wie auch das IgG wurden mittels ELISA untersucht. Die Aviditätsbestimmung basierte auf zwei parallel durchgeführten IgGBestimmungen: Bei einer von beiden wurde zwischen dem ersten und dem zweiten Inkubationsschritt mit einer 5M Harnstofflösung inkubiert (dabei lösen sich niedrig-avide Antikörper ab). Der relative Aviditätsindex errechnete sich als Quotient der Extinktionen mit und ohne Harnstoffbehandlung, wobei ein RAI unter $40 \%$ als Ausdruck einer frischen Infektion gewertet wurde.

Ergebnisse: Die Seren aller Patienten mit einer frischen Masern-Infektion wiesen einen RAI zwischen $4 \%$ und $41 \%$ (Durchschnitt: $13 \%$ ) sowie Masern-spezifisches IgM auf. Bei den SSPE-Patienten lag der RAI zwischen 73\% und 94\% (Durchschnitt: 83\%). Blutspender mit vor Jahren abgelaufener Masern-Infektion sowie Probanden mit über sechs Monate zurückliegender Masern-Impfung zeigten einen RAI zwischen $49 \%$ und 100\% (Durchschnitt: 84\%). Im Serum von drei Patienten mit akuter EBVInfektion wurden (grenzwertig) Masern-spezifische IgM-Antikörper in Kombination mit hoch-avidem Anti-Masern-IgG (RAI-Durchschnitt: 88\%) nachgewiesen. Bei einem Patienten mit positivem Befund im AntiMasern-IgM konnte der Verdacht auf akute Masern durch den Nachweis von Masern-spezifischem IgG hoher Avidität (RAI: 84\%) widerlegt werden: Diesem Fall lag eine akute Infektion mit Parvovirus B19 zugrunde, verifiziert durch Parvovirus-spezifisches IgM sowie Serokonversion im IgG.

Schlussfolgerungen: Die Bestimmung niedrig-avider IgG-Antikörper gegen Masern mittels ELISA bietet die Möglichkeit einer serologischen Absicherung frischer Masern-Infektionen, zusätzlich zur IgM-Bestimmung. Umgekehrt erlaubt das Vorliegen von hoch-avidem IgG den Ausschluss einer frischen Masern-Infektion, insbesondere bei IgM-Persistenz oder polyklonaler IgM-Synthese (z.B. im Verlauf einer aktiven Infektion mit EBV oder Parvovirus B19).

Erste Erfahrungen zur Akzeptanz der HPV-Impfung:Durchimpfungsrate eines Jahrgangs in einer Großstadt ein Jahr nach Impfempfehlung durch die STIKO

H. Roggendorf

Kinder-und Jugendgesundheitsdienst Gesundheitsamt Essen

Fragestellung: Nach der Zulassung der Impfung in Deutschland im September 2006 hat die STIKO Mitte März 2007 die Einführung einer generellen Impfung gegen humane Papillomaviren für alle Mädchen im Alter von 12 - 17 Jahren empfohlen. Ziel dieser Pilotstudie war es die Akzeptanz der HPV-Impfung bei 15 jährigen Schülerinnen an allen weiterführenden Schulen in Essen zu untersuchen.

Material und Methode: Allen Schülerinnen der 10. Klasse (15 Jahre) an allen Schulen im Stadtgebiet von Essen wurde eine individuelle Impfberatung mit Kontrolle des Impfausweises angeboten. Zunächst wurden die Schulleiter, Lehrer und Eltern durch ein Informationsschreiben über die Aktion informiert. Sie wurden gebeten an einem festgesetzten Tag die Impfbücher der Schülerinnen der 10. Klassen einzusammeln. Es wurde der Impfstatus aller Impfungen einschließlich HPV erhoben. Speziell geschulte Medizinstudenten der Universität Duisburg-Essen führten die Impfbuchkontrollen durch. Den Schülerinnen wurde eine konkrete Mitteilung auf dem Impfberatungsbogen gemacht, welche Impfungen fehlten oder aufgefrischt werden müssten. Diese sollten bei den entsprechenden Kinder- und Jugendärzten bzw. Hausärzten erfolgen.

Ergebnisse: Insgesamt haben 1711 von 2301 Schülerinnen (74\%) der 10. Klassen an allen Essener Schulen vom Angebot einer individuellen, generellen Impfberatung Gebrauch gemacht und ihre Impfausweise zur Einsicht vorgelegt. Von den 1711 der Schülerinnen, die ihren Impfausweis abgaben, hatten 760 (44\%) mit der Impfung begonnen. 588/ 760 (77\%) waren schon 2x geimpft. 321/ $760(42 \%)$ der Mädchen waren bereits $3 \mathrm{x}$ geimpft. Wir fanden eine Schultyp abhängige Akzeptanz Gymnasium> Gesamtschule> Realschule> Hauptschule > Förderschule zwischen $51 \%$ und $25 \%$.

Schlußfolgerungen: Erfreulicherweise waren ein Jahr nach Empfehlung der HPV Impfung durch die STIKO 760 von 1711 der Mädchen (44\%), von denen wir Impfbücher vorgelegt bekamen, mindestens einmal gegen HPV geimpft. Von diesen hatten $77 \%$ schon 2 Impfungen erhalten und bei $42 \%$ war die Impfserie bereits abgeschlossen. Die Abgabefrequenz der Impfbücher ist nicht nur stark abhängig vom Schultyp sondern auch vom individuellen Engagement der Lehrer und deren Einstellung zu Impfungen. Insgesamt ist die Akzeptanz der HPV Impfung ein Jahr nach Impfempfehlung durch die STIKO als gut zu bezeichnen, da $42 \%$ der Geimpften schon 3 Impfungen erhalten hatten. Die Impfempfehlung wurde also zügig umgesetzt. Besondere Aufklärung über die HPV Impfung, aber auch alle anderen Impfungen, ist in Haupt- und Förderschulen besonders nötig. In Zusammenarbeit mit Medizinstudenten bietet der Kinder- und Jugendgesundheitsdienst am Gesundheitsamt in Essen diesen Schulen nun einen zweistündigen Impfunterricht an. 
Varizellen-Durchimpfungsrate bei Kindern und Jugendlichen im Raum München - Ergebnisse aus jährlichen Elternbefragungen im Rahmen des Bayerischen Varizellen-Surveillance-Projektes (BaVariPro) A. Streng, I. Schicker, M. Piechatzek, K. Seeger, A. Köhn, V. Grote, J. Liese Dr. von Haunersches Kinderspital, LMU München

Fragestellung: Seit 2004 besteht die generelle Empfehlung der STIKO, alle Kinder zwischen 11 und 14 Monaten gegen Varizellen impfen zu lassen. Ein Ziel des Bayerischen Varizellen-Surveillance-Projektes ist die Erhebung der Varizellen-Durchimpfungsraten bei Kleinkindern in Stadt und Landkreis München. Zusammenhänge zwischen der Impfbereitschaft der Eltern und deren Einflussfaktoren sollen aufgeklärt werden.

Methode: Ende 2006 und Ende 2007 wurde eine Stichprobe von je 600 Eltern von Kindern im Alter von 18-36 Monaten in München (d.h. ca. o,3 $\%$ aller Münchener Kinder $\leq 16$ Jahre) über die Einwohnermeldeämter per Zufallsauswahl ermittelt. Die ausgewählten Familien erhielten einen Fragebogen zur Impfung; zusätzlich wurden demographische Daten zu Kind und Eltern, sowie zu den Lebensumständen der Familie erfasst.

Ergebnisse: Bei den Befragungen 2006 bzw. 2007 lag die Antwortrate bei 372 (62\%) bzw. 364 (61\%) ausgefüllten Fragebögen. Das Alter der Kinder lag in beiden Jahren im Median bei 30 Monaten. Demographische Daten und Lebensumstände waren gut vergleichbar, außer einer signifikanten Zunahme des Anteils an Krippenbesuchern (> 10h /Woche) von $45 \%$ in 2006 auf 54\% in 2007. Der Großteil der Kinder (87\% bzw. 82\%) war bisher nicht an Varizellen erkrankt. In beiden Jahren hielten 56\% der Eltern die Varizellenimpfung für sinnvoll, ca. 1/4 fand sie überflüssig, und ca. 1/5 hatte noch Beratungsbedarf. Im Jahr 2006 waren 38\%, 2007 hingegen bereits $51 \%$ gegen Varizellen geimpft, während $87 \%$ bzw. $89 \%$ eine Masernimpfung (mindestens 1 Dosis) erhalten hatten. In beiden Jahren bestand ein deutlicher Zusammenhang zwischen ärztlicher Empfehlung und Impfstatus. Der Anteil der Ärzte, die die Varizellenimpfung empfahlen, stieg von $48 \%$ auf $57 \%$. Das Alter bei Varizellenimpfung (Median) sank von 15 auf 13 Monate; das Alter bei Masernimpfung lag in beiden Jahren bei 13 Monaten. Der Anteil des Kombinationsimpfstoffes MMRV stieg 2007 auf $20 \%$ an.

Diskussion: Die Beteiligung war bei beiden Befragungen gut; aufgrund des überdurchschnittlich hohe Ausbildungsstandes der antwortenden Eltern ( $>50 \%$ mit Abitur) sind die Ergebnisse nur eingeschränkt repräsentativ. Im untersuchten Elternkollektiv war die Empfehlung durch den betreuenden Arzt ausschlaggebend für die Impfentscheidung; Einkommen oder Ausbildungsstand der Eltern hatten keinen Einfluss. Ca. 2,5 Jahre nach der generellen Impfempfehlung war die Durchimpfungsrate der 18-36 Monate alten Kinder mit 38\% noch relativ niedrig, stieg aber 2007 auf $51 \%$ an. Ein bevorzugter Einsatz von MMRV-Impfstoff würde aufgrund der hohen Akzeptanz der Masernimpfung zu hohen Durchimpfungsraten auch bei Varizellen führen, wie sie zur Erreichung von Herdenimmunitätseffekten wünschenswert sind.

Schlussfolgerung: Die Weiterführung der zeitnahen Erhebung von Durchimpfungsraten ist notwendig, um mögliche Defizite und deren Ursachen rechtzeitig zu erkennen.

\section{A phase I, randomized, controlled, double-blind trial to evaluate the safety and immunogenicity of 30 and $100 \mu \mathrm{g}$ of malaria vaccine candidate GMZ2 in Gabonese children aged 1-5 years}

S. Belard' ${ }^{1,2,3}$, F. Schaumburg', A.B. Hounkpatin', P. Martinez de Salazar', R. Mürbeth', G. Pürkenhauer', S. Issifou', B. Mordmüller, ${ }^{1,2}$, P.G. Kremsner ${ }^{1,2}$ ${ }^{1}$ Medical Research Unit, Albert Schweitzer Hospital, Lambaréné, Gabon ${ }^{2}$ Institute for Tropical Medicine, Department for Parasitology, University of Tübingen, Germany

${ }^{3}$ Department of Pediatrics and Adolescent Medicine, University of Freiburg, Germany

Background: Insecticide resistant vectors and drug resistant parasites made development of effective malaria vaccines one of the most important strategies for reducing the global burden of malaria morbidity and mortality. Strong backup of malaria vaccine development has brought up promising candidates which are now in clinical evaluation. The malaria vaccine candidate $\mathrm{GMZ}_{2}$ is a recombinant hybrid of the Glutamate Rich Protein (GLURP) and the Merozoite Surface Protein 3 (MSP 3); it has been developed at Staten Serum Institute/European Malaria Vaccine Initiative in Denmark and is now sponsored by African Malaria Network Trust (AMANET). Following promising results from phase I trials in German and African adults, this trial now aimed at evaluating safety and immunogenicity profiles for the first time in the target population of young African children.

Methods: The primary objective was to evaluate the safety and reactogenicity of three doses of 30 and $100 \mu \mathrm{g} \mathrm{GMZ}_{2}$, adsorbed on aluminium hydroxide, in comparison with three doses of the control vaccine (rabies), in healthy Gabonese children aged 1-5 years. The children received three doses in one month intervals and were closely followed up after every immunization for safety and reactogenicity. Safety evaluation is ongoing for one year after the first vaccination. Reactogenicity and safety were assessed by incidence and severity of local and systemic solicited adverse events and clinical or laboratory unsolicited or serious adverse events, respectively. Further objectives were to assess the humoral immune response to the vaccine antigens GLURP and $\mathrm{MSP}_{3}$ by measuring the total IgG concentration and IgG isotypes by ELISA and to assess Bcell memory by memory B-cell ELISPOT.

Results: The study started in October 2008 at the Medical Research Unit of the Albert Schweitzer Hospital in Lambaréné, Gabon, where 30 healthy children were enrolled and randomly allocated to receive either the 30 or $100 \mu \mathrm{g} \mathrm{GMZ}_{2}$ vaccine or the rabies vaccine. All participants received three doses of the respective vaccine and follow-up is ongoing until the end of 2009. As during the vaccination period no safety concerns arose, preliminary data suggest that the GMZ2 vaccine has an acceptable safety profile. Detailed analyze of clinical data and immunologic results are under evaluation.

Conclusion: In this trial the GMZ2 malaria vaccine candidate was for the first time given to children. The vaccination period has been completed while follow-up is still ongoing. Preliminary data suggest an acceptable safety profile. With the support of final analyze this promising malaria vaccine candidate will proceed to further steps of clinical evaluation.

\section{Hygiene-Tipps für Kids im Krankenhaus}

A.Simon, C.llschner, J. Gebel

Zentrum für Kinderheilkunde und Institut für Hygiene und öffentliche Gesundheit, Universitätsklinikum Bonn

Hintergrund: Kinder, die aufgrund einer chronischen Erkrankung immer wieder mit Spezialambulanzen in Kontakt kommen oder stationäre Behandlungen benötigen, haben ein erhöhtes Risiko für Infektionen, die im Zusammenhang mit medizinischen Maßnahmen erworben werden (nosokomiale Infektionen). Enge Kontakte mit dem Personal, mit anderen Patienten und Besuchern sowie indirekte Kontakte mit Gegenständen in der Umgebung der Patienten beim gemeinsamen Spiel führen zu einer Vielzahl an Übertragungsmöglichkeiten. Die Risiken variieren in Abhängigkeit von der Grunderkrankung, vom Immunstatus der Patienten, vom Lebensalter und vom Einsatz invasiver Hilfsmittel (Gefäßkatheter, Beatmung, Tracheostoma, Ernährungssonden usw.). Außerdem spielt eine wichtige Rolle, wie intensiv die Patienten bzw. die erwachsenen Bezugspersonen über grundlegende Präventionsstrategien zur Vermeidung von nosokomialen Infektionen informiert werden. Die Patienten und die Familie müssen in Kliniken und Spezialambulanzen stärker als Partner in der Infektionsprävention und -kontrolle einbezogen werden.

Projektbeschreibung: $\mathrm{Zu}$ diesem Zweck hat das Institut für Hygiene und Öffentliche Gesundheit der Universität Bonn hat in Zusammenarbeit mit dem Zentrum für Kinderheilkunde des Universitätsklinikums Bonn das Projekt „Hygiene-Tipps für Kids im Krankenhaus“ ins Leben gerufen. Dieses Projekt wird von allen führenden pädiatrischen und krankenhaushygienischen Fachgesellschaften und -verbänden mitgetragen und insbesondere von der Deutschen Gesellschaft für Krankenhaus- 
hygiene sowie einer Reihe von Industriepartnern finanziell unterstützt. Mit dieser Initiative soll erreicht werden, dass die Patienten sowie ihre Familien als aktive Partner in infektionspräventive Konzepte eingebunden und die spezifischen Gegebenheiten im Alltag einer pädiatrischen Station berücksichtigt werden. Hier liegt ein Potential, das bisher wenig genutzt wurde. Zielgruppe des Projekts sind primär chronisch kranke Kinder, die wiederholt im Krankenhaus behandelt werden, und ihre Familien. Durch strukturierte, persönliche Unterweisung von Patient und Familie mit Hilfe ansprechend gestalteter und kindgerechter Materialien soll eine Verbesserung und Ritualisierung im Hygieneverhalten erzielt werden, die zu einer Abnahme der Infektionsgeschehen führt und so die Lebensqualität der Kinder im Krankenhaus verbessert. Der Teamgedanke von medizinischem Personal, Patient und seinen Bezugspersonen wird betont. Das Projekt folgt dem Multibarrierekonzept der Hygiene, setzt jedoch einen deutlichen Schwerpunkt auf die Händehygiene. Weitere Themen sind die Übertragung über Lebensmittel, Umgebungsflächen sowie Spielzeug und Tiere und der aerogene Infektionsweg. Darüber hinaus gibt es Informationen für Klinikclowns, Pflegepersonal und Besucher.

\section{Use of palivizumab in Germany: data from five consecutive respira- tory syncytial virus-seasons (2002-2003 to 2006-2007)}

A. Müller, N.Heinrich, P. A.Simon

Working Group on Paediatric Infectious Diseases, Children's Hospital Medical Centre, University of Bonn, Germany

Palivizumab (Synagis(r) Abbott GmbH, Wiesbaden), a humanized monoclonal antibody produced by recombinant DNA technology, directed to an epitope of the F-protein of respiratory syncytial virus (RSV), has been recommended by German Society for Paediatric Infectious Diseases for prophylaxis of severe lower respiratory tract RSV infection in premature infants with chronic lung disease (CLD). After Feltes et al. had proven a significant benefit of palivizumab prophylaxis in children with hemodynamically significant congenital heart disease the German Society of Paediatric Cardiology recommended the use of palivizumab in these high risk patients on January 2004. The German 'Synagis Registry' represents a series of observational post marketing studies performed by the manufacturer which provides data on drug administrationl; the frequency of RSV-related hospitalization between first passive immunization and 30 days after last passive immunization in the RSV seasonl; and the compliance rate among parents of infants treated with palivizumab. Between September 01, 2002 and May 31, 2007, i.e. in 5 RSV seasons, a total of 10,686 patients received at least one injection of palivizumab. The number of children in the corresponding seasons was 853 (8\%), 20022003।; 1,287 (12\%), 2003-2004〉; 2,208 (21\%), 2004-2005\; 3,000 (28\%), 2005-2006); and 3,338 (31\%), 2006-2007. The median gestational age at birth was 29 weeks (range 23-41 weeks) \; the median birth weight was $1,350 \mathrm{~g}$. The combination of preterm birth and CLD was present in $44.5 \%$ (2002-2007) and decreased from $53.6 \%$ in $2002-2003$ to $40.9 \%$ in $2006-$ 2007. The detailed presentation of the observational results derived from the German 'Synagis Registry' adds important information to the available data on palivizumab use in high risk infants in Germany. 